DOE Award Number: DE-FC36-02GO12110, M001

Makah Renewable Energy Feasibility Study in Neah Bay Washington

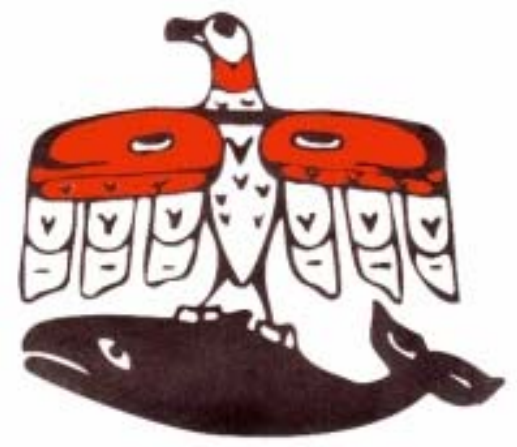

Final Report

\title{
Comprehensive Renewable Energy Feasibility Study For the Makah Indian Tribe
}

Period covered: September 2002 through March 2005

Date of Report: March 31, 2005

Recipient Organization: Makah Indian Tribe

Leonard A. Denney

Planning and Economic Development Manager

Makah Indian Tribe

P.O. Box 115

Neah Bay, WA 98357

Phone: 360-645-3281; Fax: 360-645-2033

E-mail:mtcbud@centurytel.net

Alternate Tribal contact: Ryland Bowechop

Planner

E-mail: mtcplss@centurytel.net

Technical Contact: Robert Lynette, Springtyme Company LLC

212 Jamestown Beach Lane, Sequim, WA 98382

Phone: (360) 681-3289; Fax: (360) 681-7509

E-mail:windnrg@olypen.com 


\section{Table of Contents}

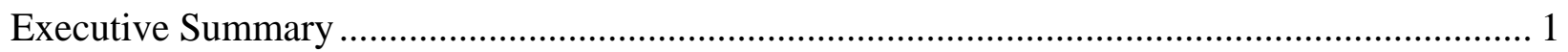

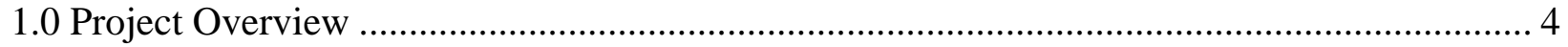

1.1 Project Purpose and Long-Term Objectives ………............................................................. 4

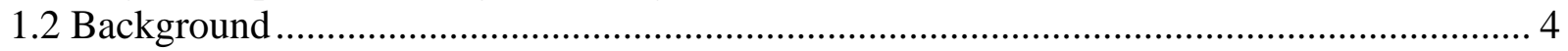

2.0 Wind Energy Pre-development Activities and Results............................................................. 7

2.1 Wind Energy Tutorial ........................................................................................................ 7

2.2 Identification of Anemometry Sites and Equipment Installation ......................................... 8

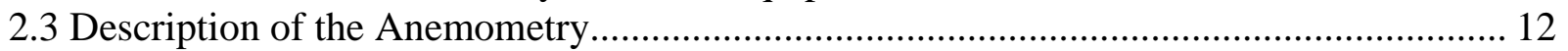

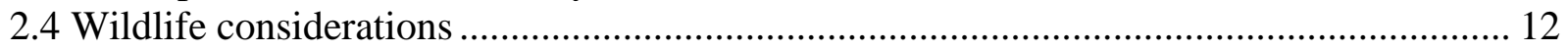

2.5 Wind Resource Measurement, Analysis, and Results ......................................................... 13

2.6 Transmission Considerations ............................................................................................. 17

2.7 Economic Analysis for a Potential Wind Power Station ..................................................... 17

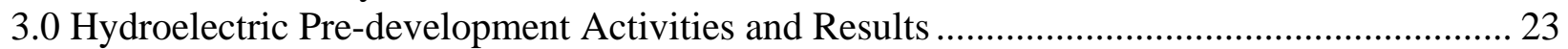

3.1 Field Trips and Identification of Potential Sites ……....................................................... 23

3.2 General Considerations, .................................................................................................. 23

3.3 Cape Creeks Development................................................................................................ 25

3.4 Waatch River Development ....................................................................................... 30

3.5 Cost of Energy for the Hydroelectric Projects ......................................................................... 34

3.6 Conclusions, Lessons learned, and Recommendations for Hydroelectric Projects............. 35

Appendix A, Final Meteorological Report for the Makah Tribe ...Error! Bookmark not defined. Appendix B, Final Hydroelectric Report for the Makah Tribe.......Error! Bookmark not defined.

\section{List of Figures and Tables}

FIGURE 1: LOCATION OF THE MAKAH RESERVATION....................................................................... 4

Figure 2, The Makah Reservation in the NW CoRner of the Olympic Peninsula................ 5

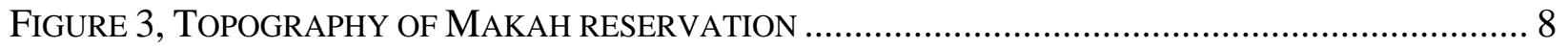

FiguRE 4, LOCATION OF METEOROLOGICAL TOWERS ON MAKAH RESERVATION .............................. 9

TABLE 1, METEOROLOGICAL TOWERS INFORMATION …………………...................................... 9

FIGURE 5, LOOKING EAST TOWARDS NEAH BAY FROM SITE MCB ……..................................... 10

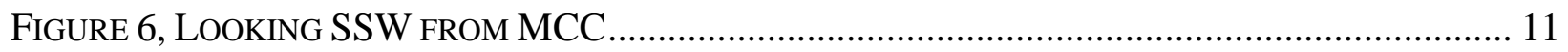

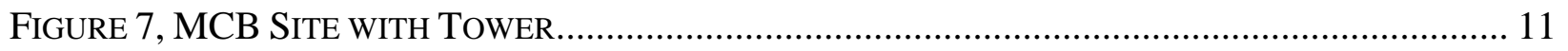

TABLE 2, WIND SPEED AND GROSS CAPACITY FACTORS FOR THE SITES ……………....................... 14

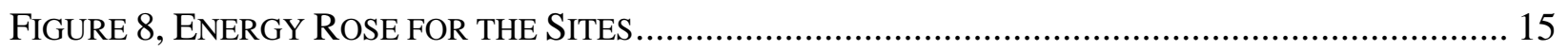

FIGURE 9, GROSS CAPACITY FACTOR BY MONTH FOR THE SITES ………………......................... 16

TABLE 3, CALCULATION OF NET CAPACITY FACTOR FROM GROSS CAPACITY FACTOR.................... 16

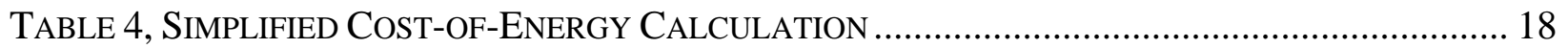

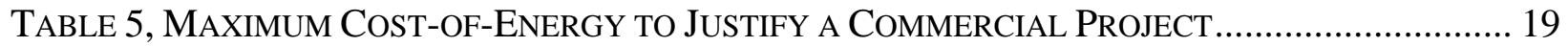

TABle 6, IMPACt Of LOW-COST FINANCING AND/OR GRANT FundS APPLIED to the PROJECT .... 20

FIGURE 10, COST OF ENERGY VS. COST OF CAPITAL FOR THE MAKAH SITE ..................................... 21

TABLE 7, PoteNTIAL INCOME FROM LAND-LEASE RoyALTIES ........................................................ 21 


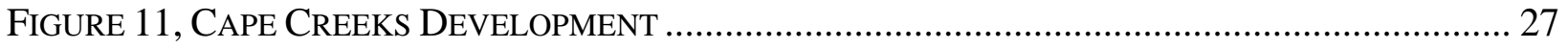

Table 8, Cape Creeks Project Cost Estimates, Including O\&M .................................... 28

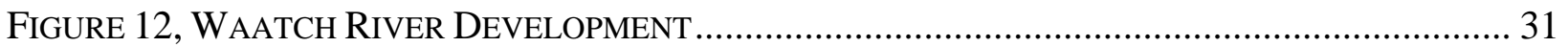

TABLE 9, COST Estimate For WAATCH PROJECT..................................................................... 33

TABle 10, Simplified Cost of ENERGy for CAPE Creeks Project ........................................ 34

TABle 11, Simplified Cost Of ENERGy for WAATCH PROJECT ............................................... 34 


\title{
Executive Summary
}

\author{
Comprehensive Renewable Energy Feasibility Study \\ For the Makah Indian Tribe
}

\section{Purpose}

The purpose of this project was to determine the technical feasibility, economic viability, and potential impacts of installing and operating a wind power station and/or small hydroelectric generation plants on the Makah reservation. The long-term objective is to supply all or a portion of Tribe's electricity from local, renewable energy sources in order to reduce costs, provide local employment, and reduce power outages. An additional objective was for the Tribe to gain an understanding of the requirements, costs, and benefits of developing and operating such plants on the reservation.

\section{Background}

The Makah Indian Reservation, with a total land area of forty-seven square miles, is located on the northwestern tip of the Olympic Peninsula in Washington State. Four major watersheds drain the main Reservation areas and the average rainfall is over one hundred inches per year. The reservation's west side borders the Pacific Ocean, but mostly consists of rugged mountainous terrain between 500 and 1,900 feet in elevation.

Approximately 1,200 tribal members live on the Reservation and there is an additional nonIndian residential population of about 300. Electric power is provided by the Clallam County PUD. The annual usage on the reservation is approximately $16,700 \mathrm{mWh}$. The existing transmission line could accommodate up to $17 \mathrm{MW}$ of new power generation for export to the North Olympic Peninsula without any substantial upgrades.

\section{$\underline{\text { Project Team }}$}

Makah Tribe: Project Coordinator - Bud Denny, Community Planning and Economic Development Manager

Ryland Bowhcop, Planner

Technical Coordinator, wind energy consultant: Springtyme Company L.L.C., Bob Lynette Wildlife: Northwest Wildlife Consultants, Inc., Karen Kronner Meteorologist: John Wade Wind Consultants, John Wade Micro/Small Hydroelectric Power: Alaska Power \& Telephone, Larry Coupe

\section{Project Work}

Project personnel, including both tribal members and consultants, conducted several site visits to identify candidate micro/small-hydro sites and locations for anemometry and potential wind power plants. Personnel had knowledge of local weather, culture, wildlife, micro-hydro, and wind energy. Several potential candidate anemometry sites as well as two micro-hydro sites were identified. Consultants also provided training of the requirements, costs, and benefits of having local renewable energy facilities. 
Wind Energy - Two anemometer suites of equipment were installed on the reservation and operated for a more than a year. An off-site reference station was identified and used to project long-term wind resource characteristics at the two stations. A report was prepared by John Wade, meteorologist that contains the details of the measured wind resources and preliminary energy production projections. Transmission resources were identified and analyzed. A preliminary financial analysis of a hypothetical wind power station was prepared and used to gauge the economic viability of installation of a multi-megawatt wind power station.

Small Hydroelectric - Two potential sites for micro/small-hydro were identified by analysis of previous water resource studies, topographical maps, and conversations with knowledgeable Makah personnel. Field trips were conducted to collect preliminary site data. A report was prepared by Alaska Power \& Telephone (Larry Coupe) including preliminary layouts, capacities, potential environmental issues, and projected costs.

This final report was prepared by Springtyme Company L.L.C. (Bob Lynette) and is based on the team's collective field trip reports, analyses, and discussion/meeting notes with team members and others as cited herein.

\section{$\underline{\text { Follow-on Contract }}$}

A follow-on contract was awarded to the Makah Tribe during 2003 to continue the work begun on this agreement. The agreement is structured to determine if the Tribe should create its own local utility, and to further refine development work leading to a utility-class wind power station, should the wind resource prove to be economically viable. Progress under that agreement is reported separately from this project.

\section{Findings and Conclusions}

Wind Energy

1. The average wind resources measured at both sites were marginal, with annual average wind speeds of 13.6 - $14.0 \mathrm{mph}$ at a 65-meter hub height, and wind shears of $0.08-0.13$. Using GE $1.5 \mathrm{MW}$ wind turbines with a hub height of 65 meters, yields a net capacity factor of approximately 0.19 .

2. The cost-of-energy for a commercial project is estimated at approximately $9.6 \nsubseteq$ per kWh using current costs for capital and equipment prices.

3. Economic viability for a commercial wind power station would require a subsidy of $40-50 \%$ of the project capital cost, loans provided at approximately $2 \%$ rate of interest, or a combination of grants and loans at substantially below market rates.

4. Because the cost-of-energy from wind power is decreasing, and because there may be small pockets of higher winds on the reservation, our recommendation is to:

- Leave one of the two anemometer towers, preferably the 50-meter southern unit MCC, in place and continue to collect data from this site. This site would serve as an excellent reference anemometer for the Olympic Peninsula. 
- If funds permit, relocate the northern tower (MCB) to a promising small site closer to the transmission line with the hope of finding a more energetic site that is easier to develop.

(The US Department of Energy has granted a follow-on contract to the Makah Tribe that might be used to implement these recommendations.)

Small Hydroelectric

1. There are a very limited number of sites on the reservation that have potential for economical hydroelectric development, even in conjunction with water supply development. Two sites emerged as the most promising and were evaluated:

- One utilizing four creeks draining the north side of the Cape Flattery peninsula (Cape Creeks), and

- One on the Waatch River to the south of Neah Bay.

2. The Cape Creeks site would be a combination water supply and $512 \mathrm{~kW}$ power generation facility and would cost a approximately $\$ 11,100,000$. Annual power generation would be approximately 1,300,000 kWh and the plant would have a cost-of-energy of approximately $65 \$$ per $\mathrm{kWh}$, substantially above market rates.

3. The Waatch site would also be a combination water supply and power generation facility. It would have a rated capacity of $935 \mathrm{~kW}$ and would cost approximately $\$ 16,400,000$. Annual power generation would be approximately 3,260,000 kWh and the plant would have a cost-of-energy of approximately $38 \$$ per $\mathrm{kWh}$, also substantially above market rates.

4. Stand-alone hydroelectric development is not commercially viable. The Tribal Council should not pursue development of hydroelectric facilities on the Makah Reservation unless they are an adjunct to a water supply development, and the water supply systems absorbs almost all the capital cost of the project. 


\subsection{Project Overview}

\subsection{Project Purpose and Long-Term Objectives}

The objective of this project is to determine if there is a potential for wind energy and/or small hydroelectric energy projects on the Makah reservation. The long-term objective is to supply all or a portion of Tribe's electricity from local, renewable energy sources in order to reduce costs, provide local employment, and reduce power outages.

The project is structured to ensure that the Makah Tribe is the focal point for data collection, analysis, and the decision making process. This provides the Tribe with the knowledge to better understand the potential for renewable energy on the reservation ${ }^{1}$.

\subsection{Background}

\subsubsection{The Makah Tribe}

Location, Size, and Topography - The Makah Indian Reservation is located in the northwest corner of the Olympic Peninsula in Clallam County, Washington. It is bounded on the west by the Pacific Ocean, on the north by the Strait of Juan de Fuca, and on the east and south by Olympic National Park. Neah Bay, its primary settlement, is 75 miles west of Port Angeles, Clallam County's government center, and more than 150 miles from Seattle, via ferry and car. The reservation is extremely isolated from other communities within Clallam County. One road - State Route 112, connects Neah Bay to the larger population centers to the east. The road is occasionally closed and power and electrical services lost due to winter storm mudslides and fallen trees. Figures 1 and 2 show the location of the Makah reservation.

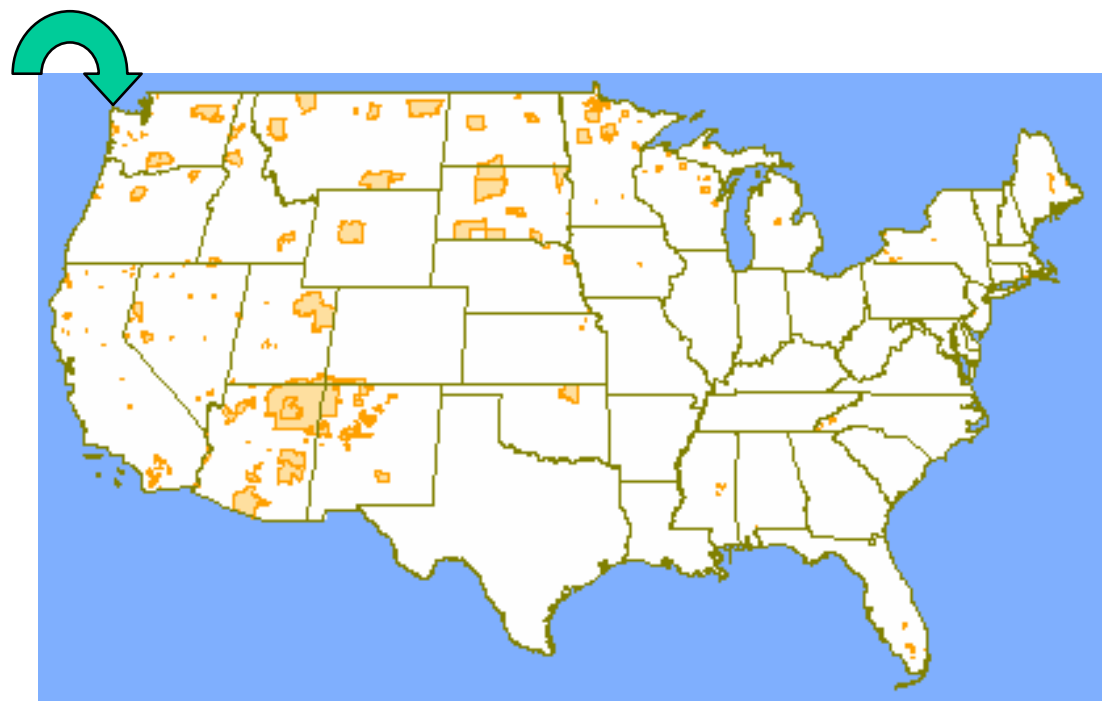

Figure 1: Location of the Makah Reservation

\footnotetext{
${ }^{1}$ In the past, several private wind power developers have expressed an interest in the potential of wind power on the reservation and two developers have done some limited wind assessments, but have never made the data available to the Tribe.
} 


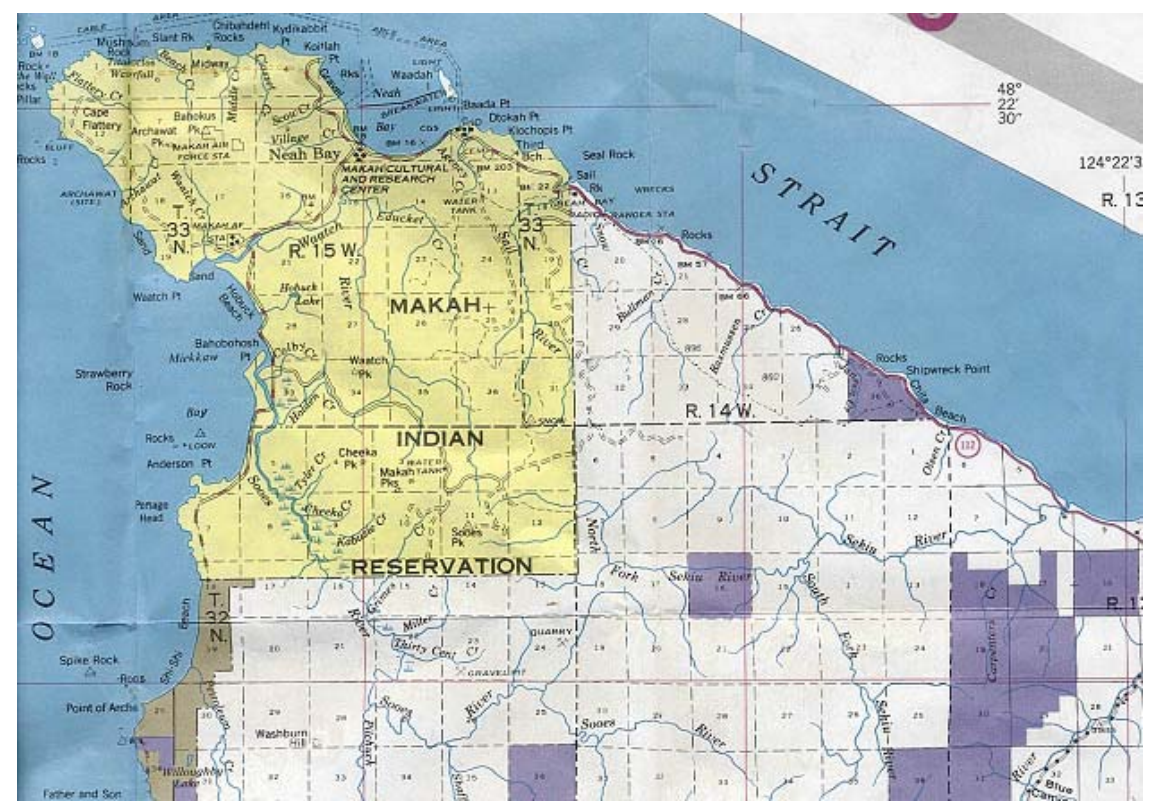

Figure 2, The Makah Reservation in the NW Corner of the Olympic Peninsula

The reservation consists of approximately 48 square miles of land and is typified by rugged mountainous terrain, mostly between 500 and 1,000 feet in elevation, and reaching nearly 2,000 feet at Sooes Peak. Rocky headlands and sandy beaches typify the shoreline of the reservation. There is one large harbor protected by a breakwater at Neah Bay. Electricity is supplied by the Clallam County PUD.

\subsubsection{Project Team}

Makah Tribe: Project coordinator - Bud Denny, Community Planning and Economic Development Manager; Ryland Bowchop, Planner Technical Coordinator, wind energy consultant: Springtyme Company L.L.C., Bob Lynette Wildlife: Northwest Wildlife Consultants, Inc., Karen Kronner Meteorologist: John Wade Wind Consultants, John Wade Anemometry installation: Met Tower Services, Mike Sailor, Chris Sailor, Jeff Baker Micro/Small Hydroelectric Power: Alaska Power \& Telephone, Larry Coupe

\subsubsection{Wind Energy Feasibility Study}

Local anecdotal information, the coastal location of the reservation, and some very limited wind resource data, indicated that the reservation could be a candidate for a wind energy project. Additionally, there is approximately $17 \mathrm{MW}$ of excess capacity on the transmission line to the reservation, enabling a wind power station to be installed without having to make significant electrical upgrades to the electrical infrastructure.

The project work consisted of:

1. Training for tribal members about wind energy - wind resource measurement, wind power plant characteristics, impacts, costs, and benefits. 
2. Identification of potential sites for installation of anemometry that:

- Were not in environmentally sensitive areas,

- Were in potentially high-wind areas,

- Did not interfere with the Tribe's current or long-range forestry plans, and

- Were accessible for work crews.

3. Installation of anemometry and measurement of the wind resources at two of the selected locations for at least a year.

4. Analysis of the wind resource data to determine wind speeds, wind directions, turbulence intensity, potential array losses, and energy generation to help determine the viability of wind power for the reservation.

5. Analysis of the electrical transmission location and capacity to determine the options for exporting energy eastward to larger load centers.

6. Analysis of the economic viability of a wind power station on the reservation.

7. If the analyses yield positive results, and the Tribal Council approves, preparation of a business plan that discusses the development considerations, costs, and potential funding sources for proceeding with a wind power project.

\subsubsection{Micro/Small Hydroelectric Power Feasibility Study}

The Makah reservation receives 80 - 100 inches of rain per year and has a number of small watersheds, making it a potential candidate for a small hydroelectric facility. The project work consisted of:

1. Preliminary screening of potential hydroelectric sites, including stream flow, head, proximity to existing transmission lines, and downstream barriers to fish migration as indicated by the size of the drainage basin.

2. Site visits, including training of Makah personnel, and data collection of:

- Topography contours

- Elevations at the possible diversion and powerhouse locations

- Selected dimensions

- Ground conditions (e.g., bedrock and soil exposures, vegetation, etc.)

3. Technical analysis, data assessment, and development of layouts for potential generating facilities.

4. Preparation of environmental, regulatory and economic assessments of the potential generating facilities.

5. Preparation of a final report for inclusion in this project report. 


\subsection{Wind Energy Pre-development Activities and Results}

This section describes the activities associated with determining the viability of developing and operating a wind power station on the Makah reservation.

\subsection{Wind Energy Tutorial}

An important element of the project was to provide the Makah personnel with a background in wind energy - from the meteorological considerations to options for wind power stations should the wind resource justify a development project.

John Wade and Bob Lynette conducted the course in February 2003 at the Makah reservation. Mr. Wade spoke to the audience about all aspects of wind resource, including:

- What wind looks like, where it is found,

- How wind reacts to surface roughness of all types,

- Topographical considerations,

- Minimum requirements for viability for wind power stations, and

- How wind is measured and converted to energy projections.

Mr. Lynette presented the following topics:

- How we find out if wind energy can work on the reservation,

- What makes a good wind power site,

- Finding good sites (wind prospecting),

- Looking at known information

- On-the-ground prospecting

- Signs of the wind

- Terrain considerations

- Measuring the wind,

- Figuring out where to place the wind turbines on a site,

- Estimating the net energy output from one or more wind turbines,

- How wind energy is used,

- What the wind turbines look like,

- Small machines and their uses,

- Big machines and wind farms,

- How wind turbines work,

- Environmental/cultural considerations,

- Operating and maintaining wind turbines, and

- What's happening in the wind energy industry around the world

The program was well received and helped tribal members gain a better understanding of 
What could be done on the reservation with wind power if the wind resource proved to be economically viable.

\subsection{Identification of Anemometry Sites and Equipment Installation}

The Makah reservation is mostly forested and the topography varies from sea level to nearly 2,000 feet. Figure 3 is a topographical map of the reservation. Much of the reservation is in active forestry management and there are numerous logging roads that provide access to potential anemometry/wind turbine sites.

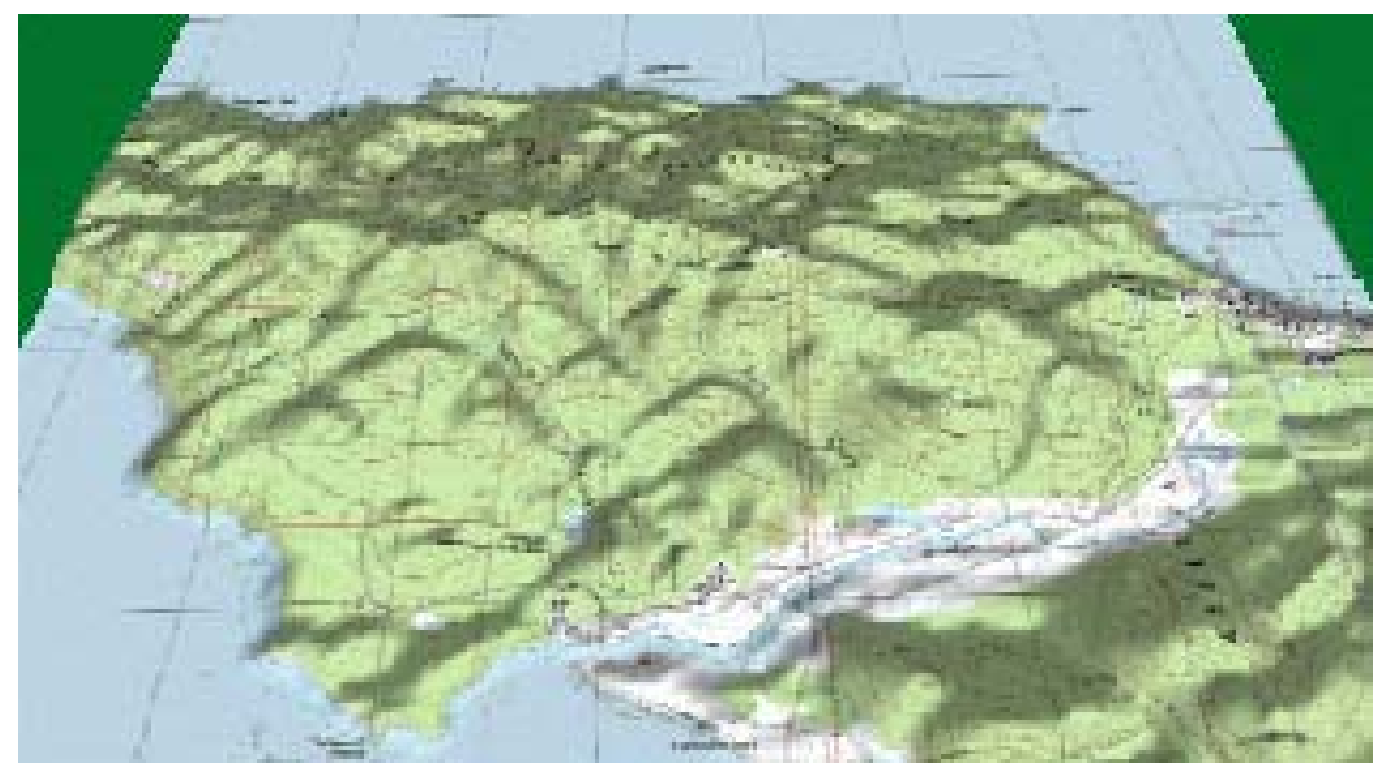

Figure 3, Topography of Makah reservation

Field trips were conducted during October 2002 and February 2003. The primary site selection criteria were:

- Attractive potential wind resources based on general known wind patterns, topography, and anecdotal information;

- $\quad$ Out of region of sensitive wildlife (e.g., marbled murrelets, spotted owl);

- Road access

- $\quad$ Reasonable transmission access (e.g., under 7 miles to transmission, preferably less)

- $\quad$ Space to site multiple utility-grade wind turbines nearby.

Two sites were selected from six potential sites, and the anemometry was installed in July 2003. Delays were encountered between the site selection and installation because of weather (heavy rainfall area) and the sites required improved access and debris clearing with a bulldozer to facilitate the installations. One 40-meter tower is located on a northwest -southeast oriented 
ridge north of the Waatch River and the other is a 50-meter tower on an east-west oriented ridge east of Cheeka Peak. The sites are designated MCB and MCC respectively. Both sites were operational on July 22, 2003 and have operated without problems for the duration of the program. Figures 4, 5, 6, and 7 show the location and pictures of the two sites, and Table 1 provides the coordinates and other site and sensor information.

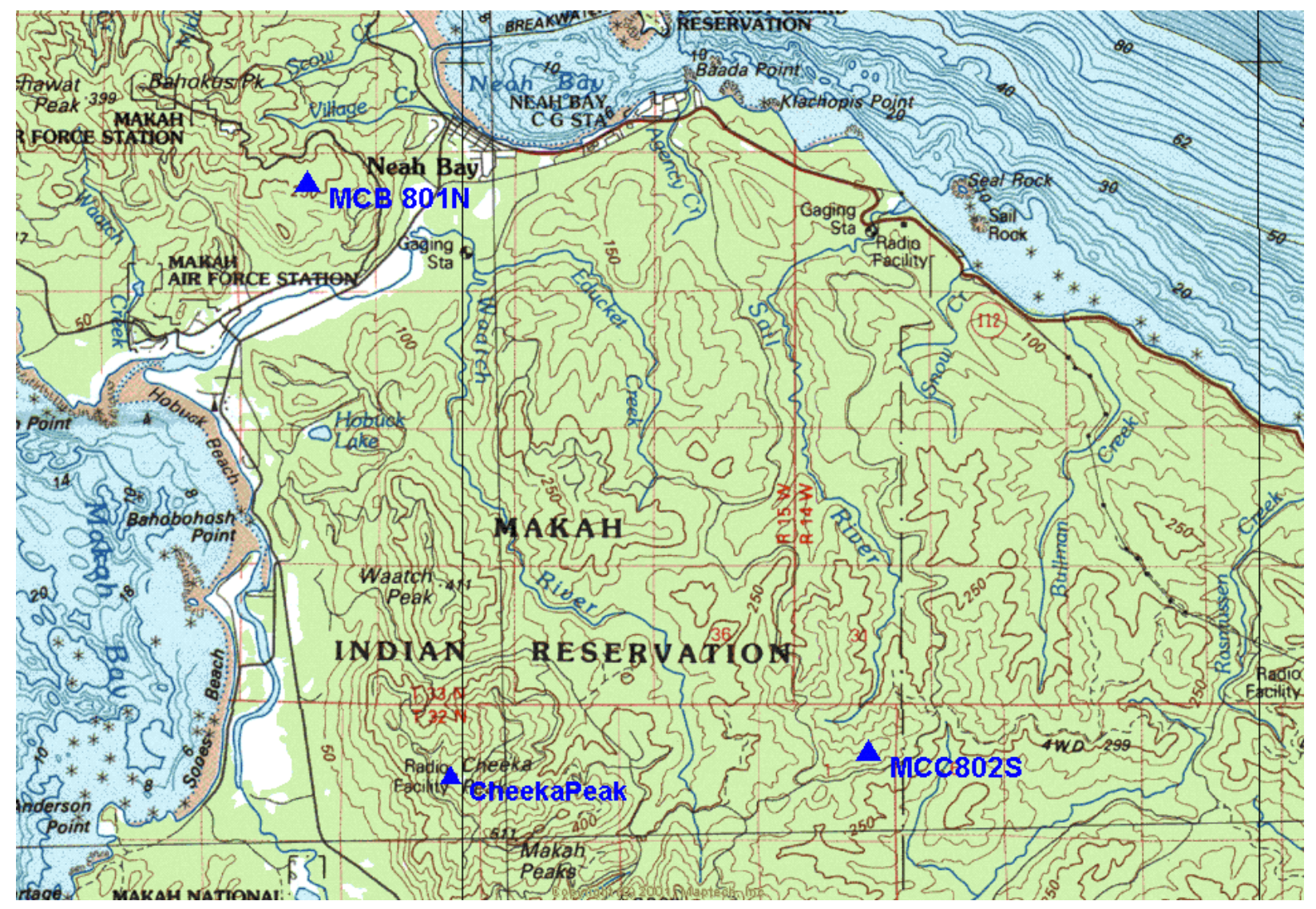

Figure 4, Location of Meteorological Towers on Makah Reservation

Table 1, Meteorological Towers Information
Site Name: MCB801 North
Elevation: $290 \mathrm{~m}$.
Latitude: $48^{\circ} 21.735^{\prime} \mathrm{N} \quad$ Longitude: 124
Legal Description: $\quad \mathrm{NE}^{1 / 4} \mathrm{NW}^{1 / 4}$ Sec 16
Terrain: Ridge line
Roughness: Spruce and Red Cedar
Prevailing Wind Direction: E, S and NW Magnetic Declination: 21 degrees East
Tower Height: 40 meters Sensor Levels: 40, 30 and 20 meters
Sensor Orientation: $40 \mathrm{~m}$ speed NW, 30m NW, and $20 \mathrm{~m} \mathrm{NW}$, directions are N. 
Table 1 (continued)

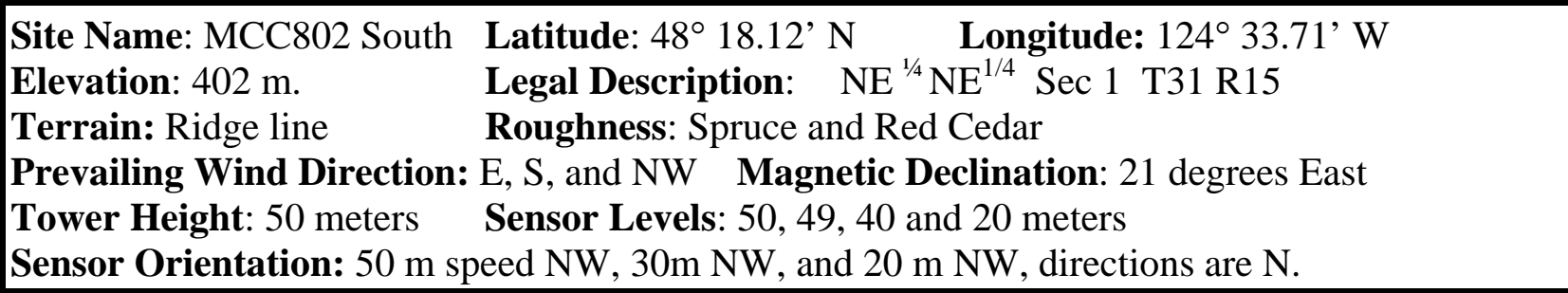

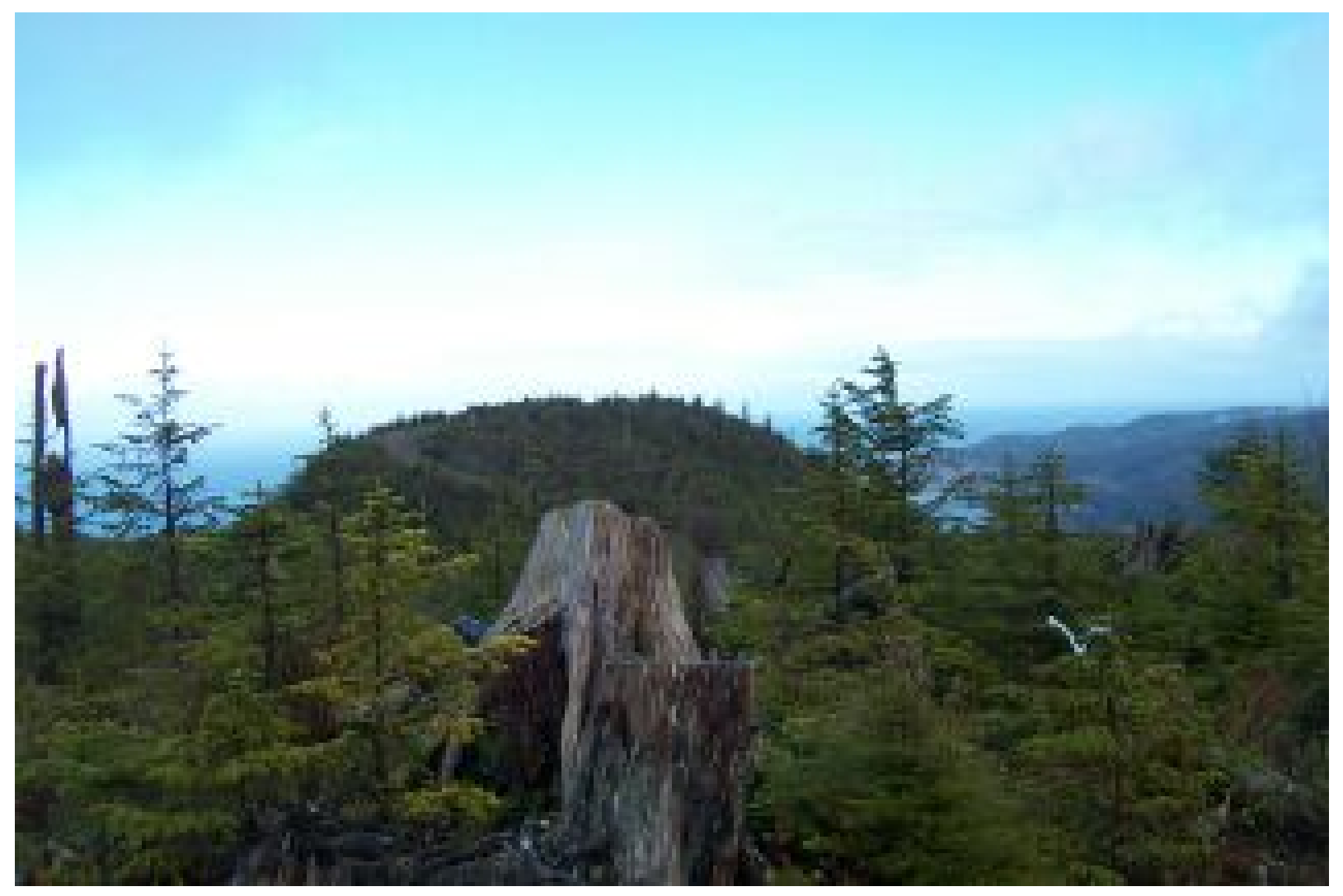

Figure 5, Looking east towards Neah Bay from site MCB 


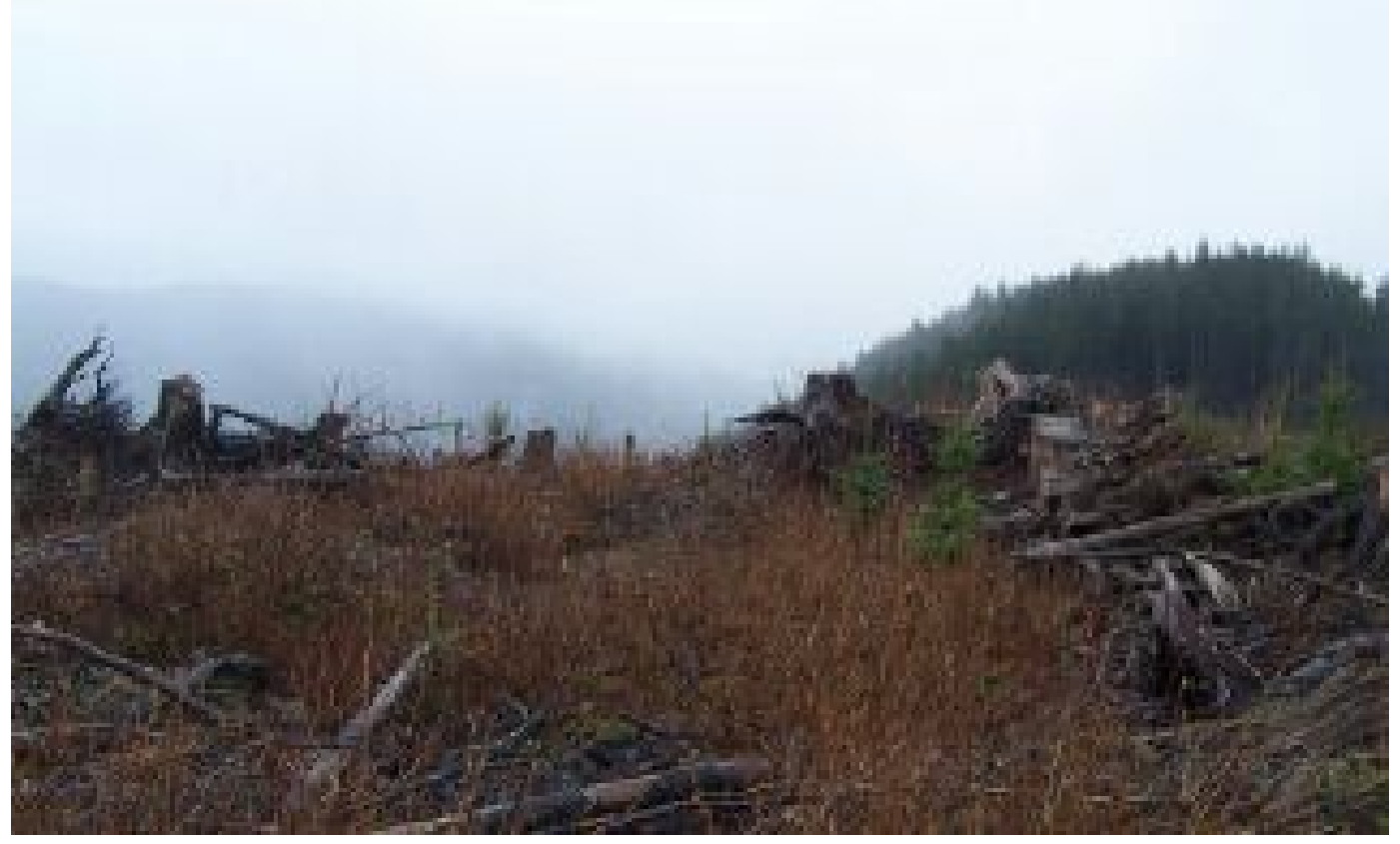

Figure 6, Looking SSW from MCC

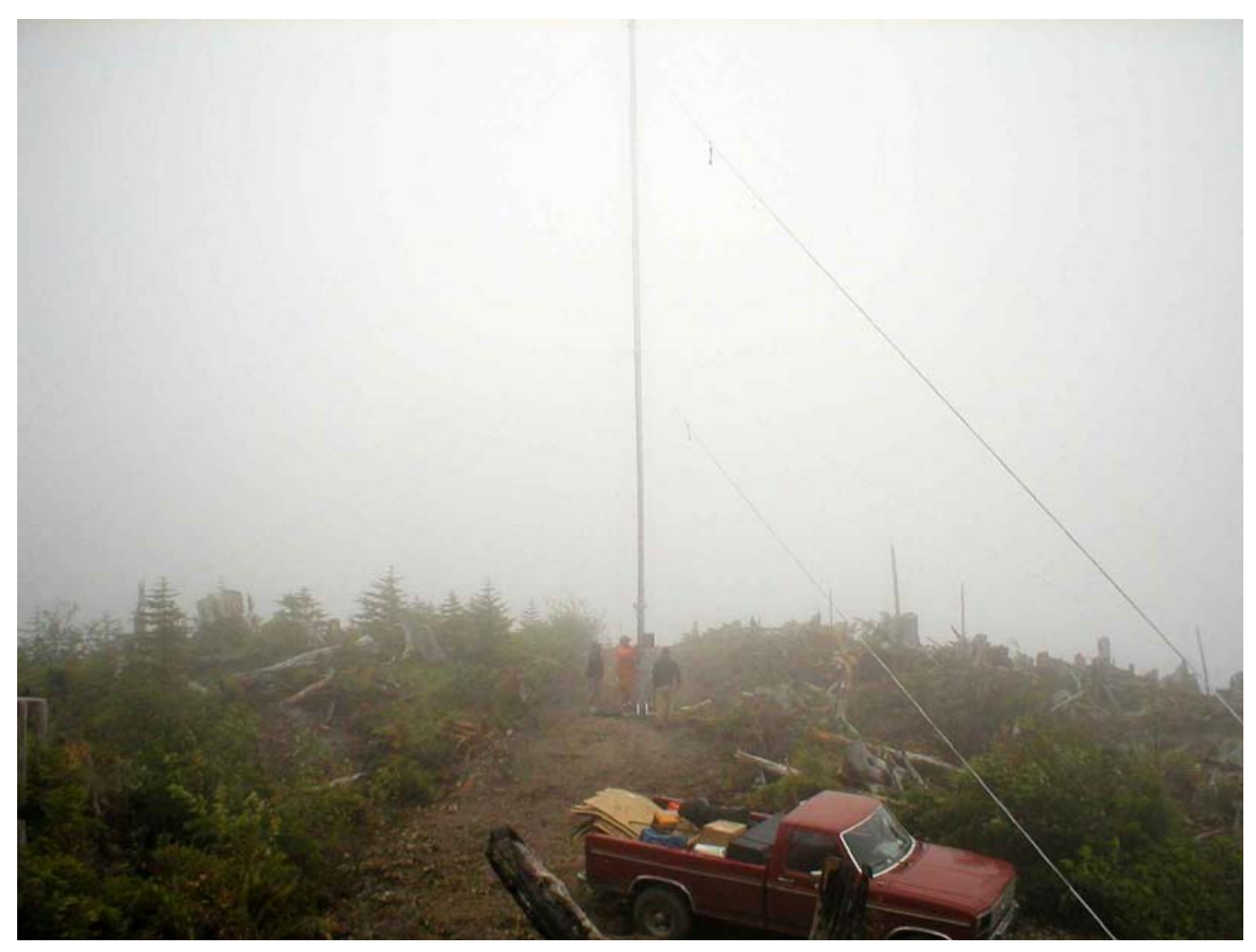

Figure 7, MCB Site with Tower 


\subsection{Description of the Anemometry}

The met towers are guyed at five levels and are instrumented at 20, 40 and 50 meters on the south tower and 40, 30 and 20 meters on the north tower. Sensors used for measuring wind speed are Maximum 40 cup anemometers with protective terminal boots. Wind direction is measured with a 200P-wind direction sensor. The tower is grounded with a lightening spike, 55 meters of copper grounding wire, and ground rod. All sensors are connected to the logger with shielded 20-gauge cable.

Each site is equipped with a NRG Symphonie Data Logger with an internal cellular phone interface with a local internet provider. A 5-watt photovoltaic panel powers the sensors and loggers. A terminal reader is supplied to program the logger on-site and view data. Having a separate display increases the logger's low temperature-operating threshold and provides security so that only authorized personnel can view the output. The data logger is backed up with nonvolatile "flash" memory cards.

Because of difficulty obtaining an analog phone set-up, the data were collected by a tribal member by swapping out the data chips. No problems were encountered using this manual method for data retrieval.

\subsection{Wildlife considerations}

Efforts were made from the onset of the program to locate the anemometry (and possible future wind turbines) in areas on the reservation that would minimize potential avian impacts. Of concern are marbled murrelets and eagles. Marbled murrelets occur in high numbers throughout the Olympic Peninsula, and they fly between foraging areas along the coast to inland breeding sites. The topography on the Makah reservation is not so high as to prevent murrelets from crossing over any ridge. The current bird use data is incomplete because studies have not been conducted throughout the reservation. Some of the field study methods are very specialized (radar).

The team's initial field trip included Ms. Karen Kronner of Northwest Wildlife Consultants and Brian Cooper and Todd Mabee, NWC subcontractors who have extensive experience with marbled murrelets, an avian species highlighted by the Makahs as a potential concern (federally listed under ESA as Threatened). Additionally, Mr. Rob McCoy, Makah Tribal Biologist, was consulted to identify potential sites that would minimize avian issues. Certain sites were eliminated because of avian considerations (e.g., coastal sites). After conducting several field trips, two sites - MCB and MCC were selected by meteorologist John Wade and technical coordinator Bob Lynette as the most promising sites from a wind power station development perspective. These sites (and other potential sites) were iterated with Ms. Kronner, who provided the following conclusion.

\section{"Recommendations}

It appears that both MCB and MCC are the preferred sites for wind anemometry exploration and will be the least problematic from a $\mathrm{T} \& \mathrm{E}$ perspective.

A more thorough, site-specific assessment is needed to determine flight paths, flight heights and densities of the avian species of concern to accurately estimate the impacts, if any from a full wind power 
development project. Data on night-migrating birds and day use information by other migrating birds would present a thorough baseline to assess impacts on T \& E species and migrating passerines. After the data is analyzed, we could conduct a risk assessment for commercial scale wind power development, answering questions from a scientific perspective using best available science. Specifically, we would need data on the following items to conduct the risk assessment: 1) morning radar surveys at all points to determine local movement patterns of murrelets, 2) avian point counts at all sites to determine numbers, species, and altitudes of raptors (and other birds of interest), especially during the spring migration and breeding seasons, and 3) maps of occupied Marbled murrelet territories in the northern Olympic Peninsula (potentially available through Washington Department of Fish and Wildlife and other databases).”

Based on this qualified recommendation, it was agreed by all team members to proceed with installation of the anemometry at sites MCB and MCC. Further avian studies would be conducted if the site proved to have a commercially-viable wind resource.

\subsection{Wind Resource Measurement, Analysis, and Results}

The wind resource data was analyzed by John Wade, principal of John Wade Wind Consultants. The following information was taken and edited by the author from Mr. Wade's final report, which is included as Appendix A of this report.

\subsubsection{Data Collection, Data Recovery, and Analysis Criteria}

Data is sent by email to Mr. Wade's office in Portland, Oregon. The Portland Oregon office is equipped with NRG data collection software and stores binary and ASCI data files for further analysis. The averaging interval of the data logger is 10 -minutes, but the data analysis uses hourly data. The raw data remains in 10-minute intervals. Data recovery was $100 \%$ for the entire period of record from late July 2003 through the end of August 2004.

Data analysis consists of spreadsheets for computing the standard analyses routines for wind energy projects, including, diurnal wind speed patterns, monthly time series, speed frequency distributions, wind roses, turbulence, shear, and expected power output calculations at anemometer height and wind turbine hub heights. For this area, the GE 1.5 MW turbine with a rotor diameter of 70.5 meters and hub height of 65 meter was used for output calculations. The air density used was $1.20 \mathrm{~kg} / \mathrm{m}^{3}$ at 801 North and $1.18 \mathrm{~kg} / \mathrm{m}^{3}$ at 802 South.

\subsubsection{Climatology}

A climatological analysis is an important part of the wind resource validation study. Typically a wind resource assessment is conducted for a period of only one to two years prior to installing wind turbines. A general rule is that a year of data is sufficient to estimate the mean annual wind speed to within $\pm 10 \%$ at the $90 \%$ confidence level. This means that the annual energy output may be off by 20 to $25 \%$. To increase the confidence in the relatively short record of data at the candidate site, data at a nearby long-term reference site can be analyzed.

The approach in the climatological analysis is to select a nearby reference station with a longterm record that would provide information on annual and seasonal variation in the wind resource. A typical approach is to multiply the long-term site mean wind speed by the ratio of the candidate site to the long-term site. Originally this report used Cheeka Peak as a climatological reference; however the data from this site was neither long-term nor reliable. In 
this report the Quillayute upper air data at an average height of 785 meters was determined to be the most useful climatological reference. Quillayute is about 25 miles south of the two wind measurement sites. Based on the measurements at the Quillayute site the period of measurement was close to normal $(+1 \%)$.

\subsubsection{Data Analysis and Results}

Table 2 summarizes the important wind speed data, and Figures 8 and 9 show the wind rose (wind directions) and seasonal variation of the wind speeds. On the plus side, there is a large seasonal variation of wind at the sites with the winter winds being much stronger than the summer winds - an advantage in the Pacific Northwest, where peak demand is in the winter. However, on the negative side, the average wind speeds are low, the wind shears are low, the winds are very bi-directional (making turbine siting difficult), and the extreme wind speeds are very high for a site with a moderate annual average wind speed. If reasonable assumptions are made to correct the gross energy output to a net energy output for this site, it is realistic to expect a Net Capacity Factor of approximately $19 \%$ for a project on the Makah Reservation. (This represents a reduction of approximately $22 \%$ from the gross capacity factors of $24-25 \%$.) The rationale for the conversion from gross to net energy is contained in Table 3. The net Capacity Factor for both sites is considerably less than a net CF of 34 - 35\%, which are the lowest capacity factors required to achieve economic commercial viability without supplemental grant funding with today’s technology, cost-of-capital, and turbine costs.

There are little differences between the CF values for the two widely dispersed wind measurement sites that are located in very different terrain. This suggests that the wind resource is consistently marginal on the reservation, although it may be possible to locate small areas of better wind resources with additional anemometer locations.

Table 2, Wind Speed and Gross Capacity Factors for the Sites

\begin{tabular}{|c|c|c|c|c|}
\hline \multirow[b]{3}{*}{ Site } & \multicolumn{4}{|c|}{ Annual Average Wind Speed (mph) } \\
\hline & \multicolumn{4}{|c|}{ Height above Ground (Meters) } \\
\hline & 20 & 30 & 40 & 50 \\
\hline MCB801 & 13 & 13.3 & 13.6 & - \\
\hline MCC802 & 11.6 & - & 12.6 & 13.1 \\
\hline Site & $\begin{array}{l}\text { Wind } \\
\text { Shear } \\
\text { (Annual) }\end{array}$ & \begin{tabular}{|c|} 
Projected \\
Wind \\
Speed at 65 \\
meters hub \\
height \\
(mph)
\end{tabular} & $\begin{array}{c}\text { Annual } \\
\text { gross CF } \\
\text { using GE } \\
1.5 \mathrm{MW}\end{array}$ & $\begin{array}{c}\text { Maximum } \\
\text { Gust } \\
\text { (mph) }\end{array}$ \\
\hline MCB801 & 0.08 & 14 & 0.24 & 101 \\
\hline MCC802 & 0.13 & 13.6 & 0.25 & 94 \\
\hline
\end{tabular}


Energy Rose for Site 801 North

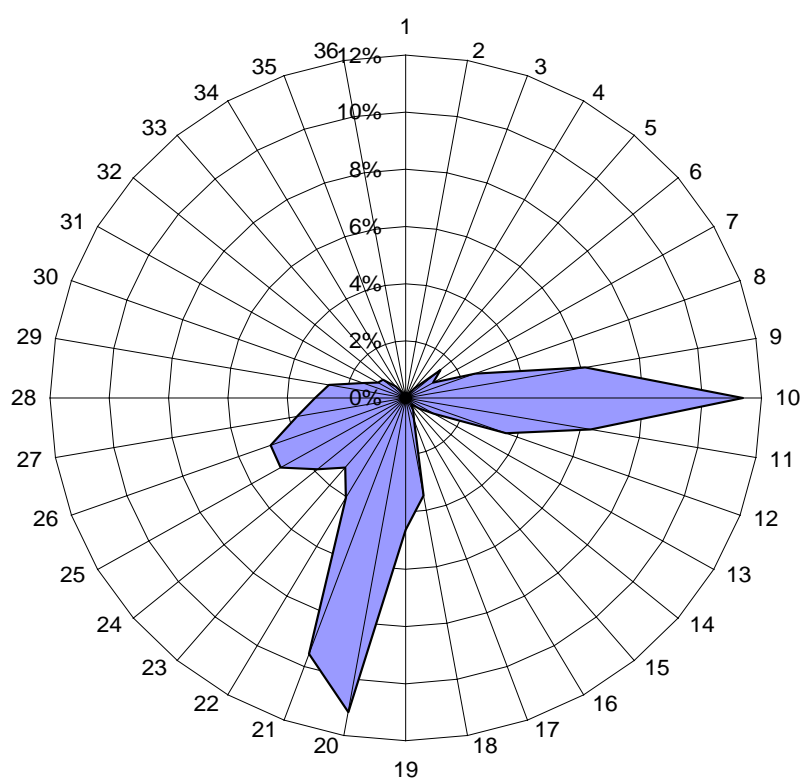

\section{Energy Rose for Site 802 South}

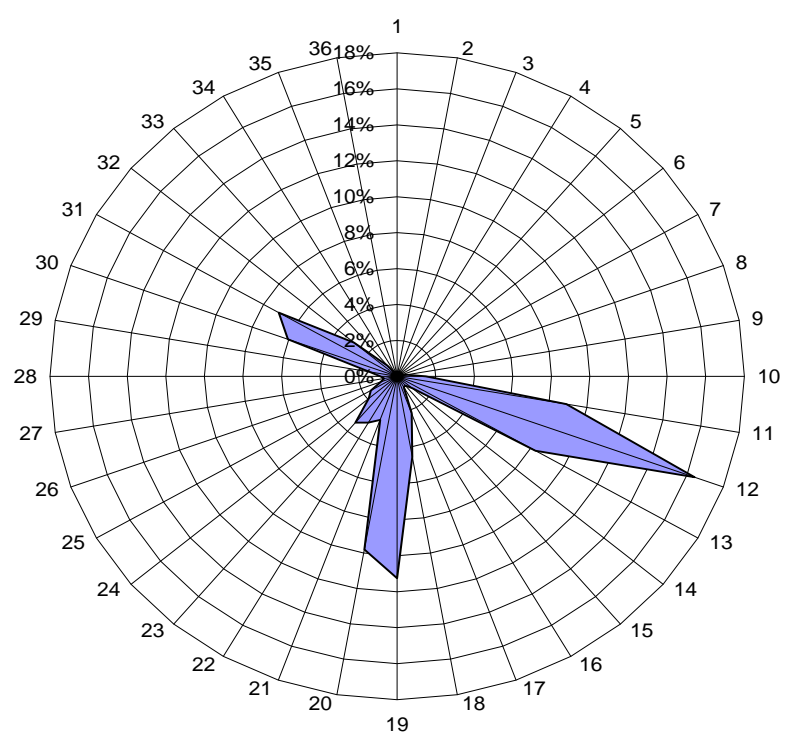

Figure 8, Energy Rose for the Sites 


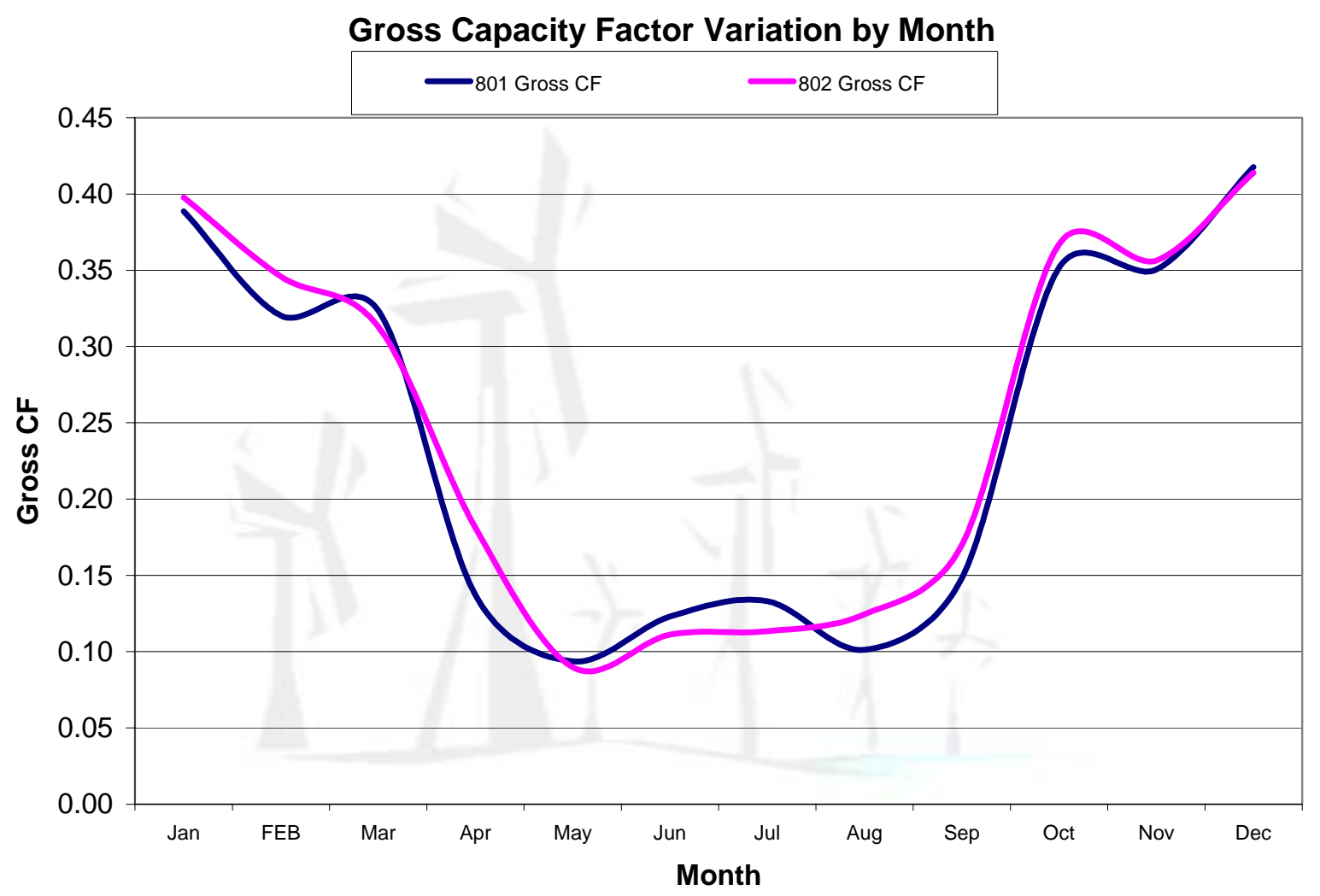

Figure 9, Gross Capacity Factor by Month for the Sites

Table 3, Calculation of Net Capacity Factor from Gross Capacity Factor

\begin{tabular}{|c|c|}
\hline Calculated Gross CF Projection ${ }^{1}$ & 0.245 \\
\hline \multicolumn{2}{|l|}{ Plant Net Output Corrections } \\
\hline Availability & 0.98 \\
\hline Array Losses & 0.9 \\
\hline Reduction for Inter-annual correction & 0.98 \\
\hline Topographic & 0.97 \\
\hline Electrical losses & 0.97 \\
\hline Turbine Power Curve & 0.98 \\
\hline Other Control Losses & 0.99 \\
\hline Hysteresis at High Winds & 1 \\
\hline \multicolumn{2}{|l|}{ (corrected for in the power curve) } \\
\hline Icing & 0.995 \\
\hline Dirty Blades & 0.995 \\
\hline Utility Forced Shutdowns & $\underline{0.997}$ \\
\hline Total Correction Gross to Net & 0.779 \\
\hline Net Capacity Factor & 0.191 \\
\hline
\end{tabular}




\subsection{Transmission Considerations}

Meetings were held with the Bonneville Power Authority (BPA), Clallam County PUD, and several consultants that are conducting studies for BPA. The purposes were to inform them of the project's activities and to gain an understanding of the electrical transmission issuess on the Olympic Peninsula.

The primary transmission system running from the mainland to the Olympic Peninsula is operated by BPA. There will be a shortage of transmission to the Peninsula commencing in 2007 (approximately $20 \mathrm{MW}$ ), so BPA has instituted a "no wires" (distributed generation) program in hopes of finding new generation on the Peninsula. However, they do not consider wind energy to qualify for the program because of its intermittent nature. The reservation is currently served by the Clallam County PUD. The PUD is very receptive to cooperating with renewable generation developers. They sell "green energy" to their customers and currently receive their renewable energy, about $1 \mathrm{MW}$, from landfill biogas generators in eastern Washington. The PUD is also cooperating with the Tribe and AquaEnergy Group, LTD, a company that is trying to develop wave energy off the reservation's west coast..

There is a $115 \mathrm{kVA}$ line running from Port Angeles to Sapho, 23 miles from Neah Bay, and a 7.5 MW substation at Neah Bay. The Makah area (Neah Bay) load is approximately $1.5 \mathrm{MW}$, and is serviced by the Clallam County PUD. According to the PUD, the Neah Bay area could generate approximately $17 \mathrm{MW}$ of firm power without major upgrades to the lines. In the opinion of the PUD's transmission engineer, this would be a reasonable limiting factor for a wind project, although more study would be warranted if the winds prove economically viable.

This project assumes that a 16.5 MW project would be developed to take advantage of the economy-of-scale inherent with larger projects, but avoids the significant transmission line and substation upgrade costs that would be required for a larger project. It also assumes that the balance-of-station costs would be at the higher end of industry-representative costs because:

- Rainfall is frequent, heavy and seasonal delays of construction are likely;

- The reservation is remote and specialized skilled labor would have to be imported and maintained during construction;

- The site is relatively far from available heavy construction equipment needed to install 1.5 MW wind turbines; and

- The terrain is forested, undulating, and more difficult to develop than most sites.

\subsection{Economic Analysis for a Potential Wind Power Station}

There are two methods generally used to determine the economic viability of a wind power project:

1. A Cost-of-Energy (COE) model used to derive an approximate cost of generation, and

2. A more complex economic model that reflects the approach used by developers and financial institutions to finance commercial projects. 
Because the wind resource results were significantly below the wind speeds generally required to achieve financial viability, the first method was chosen, since it provides results that puts the project is an easy to understand perspective.

It should be noted that the capital costs for wind turbines delivered to a US market has increased significantly during the past two years due to the weakening of the US dollar and dramatic increases in the cost for steel for the wind turbine towers. The numbers used herein reflect prices going forward to 2005 and 2006.

\subsubsection{Cost-of-Energy Calculation}

The simplified Cost-of-Energy (COE) model is:

Cost of Energy = ((fixed charge rate $\mathrm{x}$ capital cost $)+$ annual O\&M (inc. schd. replacements/overhauls)) annual net energy generation

Table 4 shows the results for values that represent the most likely costs and financing terms for a commercial project with no grants and today's (March 2005) costs for financing a project. The fixed charge rate is based on a blend of equity (12\% return) and debt ( $8 \%$ return) financing, assuming 50\% equity and $50 \%$ debt. The cost for the wind turbines $(\$ 850 / \mathrm{MW})$ is the minimum current cost for "bankable", wind turbines. The balance-of-station costs (engineering, roads, control/storage building, wind turbine foundations, monitoring and control systems, one-time installation fee by land owner, and electrical infrastructure) generally have a range of $\$ 230$ $\$ 280$ per installed MW. A value of $\$ 270$ per MW was used for this calculation to account for the difficult access and rugged, mountainous terrain, and other reasons cited previously. An installation fee of $\$ 5,000$ per wind turbine, which would be paid to the Tribe was also applied to the BOS number, which reflects typical current values.

Table 4, Simplified Cost-of-Energy Calculation

\begin{tabular}{|c|c|}
\hline Item & Nominal Values \\
\hline Project capacity (MW) & 16.5 \\
\hline Project life (years) & 20 \\
\hline Fixed charge rate & 0.1 \\
\hline Wind turbines cost (at $\$ 850 / \mathrm{kW}$ ) & $14,025,000$ \\
\hline Balance-of-station cost & $4,510,000$ \\
\hline Transaction costs ( $6 \%$ of WTG+BOS cost) & $1,112,100$ \\
\hline Total capital cost & $\$ \quad 19,647,100$ \\
\hline Annualized amortization (FCR x Capital Cost) & $(\$ 2,307,741)$ \\
\hline Annual operation \& maintenance cost ${ }^{1}$ & $(337,000)$ \\
\hline Total annualized cost & $\$ \quad(2,644,741)$ \\
\hline Annual net kWh & $27,607,140$ \\
\hline Cost of energy (COE) before royalty payments & $(0.096)$ \\
\hline
\end{tabular}

${ }^{1}$ Includes management, repairs, scheduled maintenance, blade washing, and annualized scheduled replacement/overhaul costs.

\footnotetext{
2 "Bankable” wind turbines are from well-established manufacturers with good reputations for delivering on time and carry warranties that satisfy financing entities.
} 
The annual cost of energy is approximately $9.6 \mathbb{C}$ per kWh before any set aside to cover royalty payments to the Tribe for use of the land. Table 5 shows a simplified maximum cost-of-energy that could justify a commercial project.

\section{Table 5, Maximum Cost-of-Energy to Justify a Commercial Project}

\begin{tabular}{|c|c|l|}
\hline Item & $\mathbf{\$ / k W h}$ & \multicolumn{1}{|c|}{ Notes } \\
\hline Payment from utility & 0.035 & Includes greentags \\
\hline Internalize tax credit $^{3}$ & 0.018 & Assumes Makah tribe does not own project. \\
\hline Total & $\mathbf{0 . 0 5 3}$ & "Break-even" for project \\
\hline
\end{tabular}

The payment from the Clallam County PUD has been estimated based on past informal discussions and is considered reasonable if the wholesale cost for the greentags ${ }^{4}$ are included in the price. This payment could increase to $\$ 0.04$ within the next year, depending on the condition of the hydroelectric system in the region and natural gas prices. Nevertheless, even at \$0.06 per $\mathrm{kWh}$, the project cannot be financed without including either very low cost financing and/or grant money.

Table 6 and Figure 10 show the impact of low-cost financing and partial grants on the projected cost of energy. The possible combinations that could enable the project to be "financiable" are shaded. As can be observed from the chart, it would require a grant of at least $50 \%$ of the project (almost \$10 million) to make a viable project under today's cost of capital. Alternatively, lowcost financing of $2 \%$ cost-of-capital would be required without grant funds. The likelihood of obtaining either of these conditions is considered extremely remote.

\subsubsection{Potential Benefits to the Tribe}

Based on the previous financial discussion, there is no possibility of financing this project without substantial low-cost financing and/or outright grant funds. The gap between the cost to generate the energy and the potential income is more than $4 \mathbb{\complement}$ per $\mathrm{kWh}$. However, in the event that a path is found to finance the project, (via low-cost financing and/or grant funds), this section provides a picture of the potential benefits to the Tribe.

To provide all the financial benefits available, it is assumed that the project would be owned by an entity other than the Makah tribe during the first ten years of operation, when the federal production tax credit would likely be available. During this time, the Tribe would receive royalties from the project to pay for the use of their land. Table 7 shows the potential income to the Tribe, assuming a royalty rate of $5 \%$ of the net production income from the project. This is the maximum rate considered likely from a wind project with the wind resources measured to date. Using this rate yields an annual income of approximately $\$ 76,000$.

\footnotetext{
${ }^{3}$ There is currently a federal $1.8 \$$ per kWh production tax credit (PTC) for producing energy from wind powered generation facilities available to the owner(s) of the facilities for the first ten years that the facility is in operation. The PTC expires on December 31, 2005, but observers believe that it will be renewed.

4 “Greentags" are the renewable energy element of the energy produced for which some customers will pay a premium. The price for greentags varies from \$0.003 - \$0.02 in the Pacific Northwest.
} 
In addition to this income, the project would be structured to revert to the Tribe after ten years. The income stream available to the Tribe from the project ownership is estimated to be $5 \%$ of the project's income, or approximately $\$ 76,000^{5}$. Taken together with the royalty payments, there is an income stream after the first ten years of operation of a maximum of approximately $\$ 152,000$ per year. Because of the problems associated with financing this project, it is likely that the financing agency would require the Tribe to accept a lower income level, but it is not possible to calculate this number at this stage of early pre-development.

Finally, it is assumed that the Tribe would be employed to manage, operate, and maintain the project. Based on past experience in the industry, approximately two full-time personnel would be required for the project.

Table 6, Impact of Low-cost financing and/or Grant Funds Applied to the Project

\begin{tabular}{|c|c|c|c|c|c|c|}
\hline \multirow{2}{*}{$\begin{array}{c}\text { Fixed } \\
\text { charge rate }\end{array}$} & \multirow{6}{|c|}{$\begin{array}{c}\text { No Grant } \\
\text { Financing }\end{array}$} & \multicolumn{6}{|c|}{ With Grant (\% of total capital cost) } \\
\cline { 2 - 7 } & $\mathbf{1 0 \%}$ & $\mathbf{2 0 \%}$ & $\mathbf{3 0 \%}$ & $\mathbf{4 0 \%}$ & $\mathbf{5 0 \%}$ \\
\hline $2 \%$ & 0.056 & 0.051 & 0.047 & 0.043 & 0.038 & 0.034 \\
\hline $3 \%$ & 0.060 & 0.055 & 0.05 & 0.046 & 0.041 & 0.036 \\
\hline $4 \%$ & 0.065 & 0.059 & 0.054 & 0.049 & 0.044 & 0.038 \\
\hline $5 \%$ & 0.069 & 0.064 & 0.058 & 0.052 & 0.046 & 0.041 \\
\hline $6 \%$ & 0.074 & 0.068 & 0.062 & 0.056 & 0.049 & 0.0432 \\
\hline $7 \%$ & 0.079 & 0.0727 & 0.066 & 0.0592 & 0.053 & 0.046 \\
\hline $8 \%$ & 0.085 & 0.077 & 0.07 & 0.063 & 0.056 & 0.048 \\
\hline $9 \%$ & 0.090 & 0.082 & 0.075 & 0.067 & 0.059 & 0.051 \\
\hline $10 \%$ & 0.096 & 0.087 & 0.079 & 0.071 & 0.062 & 0.054 \\
\hline $11 \%$ & 0.102 & 0.093 & 0.084 & 0.075 & 0.066 & 0.057 \\
\hline $12 \%$ & 0.108 & 0.098 & 0.088 & 0.079 & 0.069 & 0.06 \\
\hline $13 \%$ & 0.114 & 0.103 & 0.093 & 0.083 & 0.073 & 0.063 \\
\hline $14 \%$ & 0.120 & 0.109 & 0.098 & 0.087 & 0.077 & 0.066 \\
\hline
\end{tabular}

\footnotetext{
${ }^{5}$ The reader is reminded that the original rate-of-return of $12 \%$ for equity investors included the PTC, which will no longer be available after operating the project for ten years.
} 


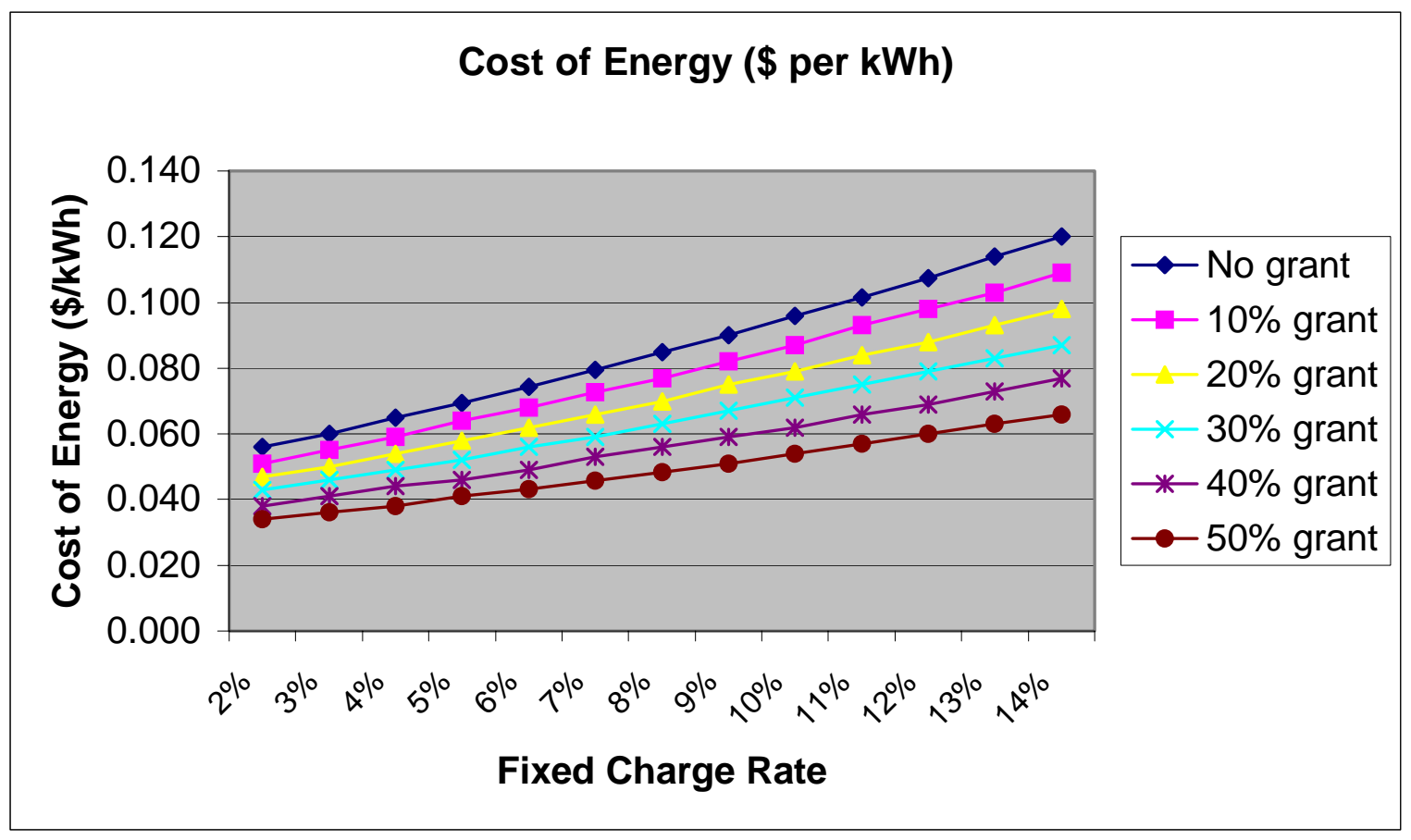

Figure 10, Cost of Energy vs. Cost of Capital for the Makah Site

Table 7, Potential Income from Land-Lease Royalties

\begin{tabular}{|c|c|}
\hline Annual net energy (kWh) & $27,607,140$ \\
\hline Reve & $\$ 1,518,393$ \\
\hline Royalty at $5 \%$ of revenue & 75,920 \\
\hline
\end{tabular}

2.7.3 Discussion of Results and Future Options

As can be seen from Table 6, financing this project would require almost a $50 \%$ grant or a very low-cost loan (2\% cost-of-capital). This means that there is little likelihood that a commerciallyviable project can be constructed at this time. Wind turbine technology has continued to show increased cost effectiveness during the past 25 years, and is expected to result in lower costs per $\mathrm{kWh}$ in the future. The goal of the Department of Energy's low-wind speed project is to reduce cost of energy from large wind systems to $3 \notin$ per $\mathrm{kWh}$ in Class 4 wind resources by 2010. This represents a reduction in the cost-of-energy of $40-50 \%$, which if achieved, and coupled with slowly increasing energy prices, could make the Makah reservation a cost-effective site within 5 -10 years. Additionally, as mentioned previously, there is a large seasonal variation of wind at the sites with the winter winds being much stronger than the summer winds - an advantage in the Pacific Northwest, where peak demand is in the winter. This could make the energy generated from a wind power station on the reservation worth somewhat more than the COE calculation provided in this section.

If funds are available, it is recommended to: 
- Leave one of the two anemometer towers, preferably the 50-meter southern unit MCC, in place and continue to collect data from this site. This site would serve as an excellent reference anemometer for the Olympic Peninsula.

- Relocate the other tower (MCB) to a promising site closer to the transmission line with the hope of finding a more energetic site that is easier to develop. As mentioned previously, the US Department of Energy has granted a follow-on contract to the Makah Tribe that might be used to implement this recommendation.

\subsubsection{Wind Energy - Lessons Learned}

Anemometry - The team that estimated the cost of installing the anemometer towers neglected to account for the costs associated with clearing sites in preparation for installing the anemometers. These costs were substantial - approximately $\$ 5,000$ total for the two sites.

Economic Viability of the Site for Wind Power - The reservation was certainly a good candidate for wind power, and there was no way of knowing that the wind resource was marginal without measuring it. The program will help the Tribe plan for the use of their lands now that they understand the wind resources. 


\subsection{Hydroelectric Pre-development Activities and Results}

Section 1.2.4 contained a description of the activities performed to determine the potential for hydroelectric development on the Makah Reservation. The purpose of this section is to document the performance of those activities and to present the results. Much of this section is taken from Alaska Power \& Telephone's report. The entire AT\&P report, carried out by Mr. Larry Coupe of Alaska Power \& Telephone, is contained in Appendix B of this report.

\subsection{Field Trips and Identification of Potential Sites}

After reviewing topographic and watershed maps, an initial reconnaissance visit to the reservation was made on October 25, 2002 by Larry Coupe of Alaska Power \& Telephone (AP\&T), Bob Lynette of Springtyme LLC, and David Lawes, Water Quality/Resource Specialist for the tribe. During the field trip, the team became aware of the critical need in Neah Bay for a reliable, good-quality water supply. It became clear that a hydroelectric development that included a water supply function could have strategic development benefits. Consequently, the work focused on sites that have some water supply potential in addition to hydroelectric potential.

Subsequent analysis revealed that there are a very limited number of sites on the reservation that have potential for economical hydroelectric development, even in conjunction with water supply development. Two sites have emerged as the most promising and are evaluated further herein:

1. One utilizing four creeks draining the north side of the Cape Flattery peninsula, and

2. One on the Waatch River to the south of Neah Bay.

A second site visit was conducted on May 27, 2003 to review structure locations selected during the preliminary studies. The second site visit was conducted by Larry Coupe of AP\&T and Jeff Shellberg, Hydrologist for the tribe.

\subsection{General Considerations,}

Development of a hydroelectric project is possible whenever there is sufficient head and flow. However, from a practical sense, development can be constrained by economics and/or environmental issues.

\subsubsection{Environmental Constraints}

The most important issue for this preliminary study has been potential impacts to anadromous fish. It is recognized that salmon play an important role in the economy and culture of the Makah Nation, as well as the Pacific Northwest in general, and a project that could adversely affect salmon runs would not be acceptable. Thus streams with salmon runs were eliminated from consideration. 
Another potentially significant environmental issue is the clearing of old growth forest. Although much of the reservation land is used for timber harvest, some portions of old growth remain that could be affected by hydroelectric developments. Old growth forest is important habitat for many species of wildlife, including two species protected by the Endangered Species Act (spotted owls and marbled murrelets).

\subsubsection{Preliminary Design Criteria}

Because the two potential hydroelectric developments have been structured as water supply projects, the same water supply criteria used by the U.S. Bureau of Reclamation for their 2002 study of potential water supplies for the reservation have been used for this study:

- Peak daily water use rate $-1.1 \mathrm{cfs}$

- Average daily water use rate (May - September) - $0.55 \mathrm{cfs}$

- Average daily water use rate (October-April) - $0.45 \mathrm{cfs}$

- Peak flow for raw water facilities $-1.5 \mathrm{cfs}$

\subsubsection{Economic Evaluation Assumptions}

Cost analysis methods used in this study are similar to those used by the U.S. Bureau of Reclamation to allow comparison of the two alternatives studied herein to those studied by the Bureau. These include:

- Contingency factor of $25 \%$ applied to the estimated construction costs.

- Construction cost of $\$ 1,752,000$ for a water treatment plant in Neah Bay

- Annual operating costs of $\$ 340,000$ for the water treatment plant.

\subsubsection{Regulatory Environment}

The Federal Energy Regulatory Commission (FERC) will likely have jurisdiction over hydroelectric developments on the reservation because the power, if sold to the Clallam County PUD, would be construed as affecting interstate commerce and because the developments would use US lands (lands held by the US in trust probably qualify as US lands). See Appendix B for details of the regulatory procedures.

Other agency permits are applied for during this process, including a 404 permit from the Corps of Engineers, a coastal zone management review, and a water quality certification. The FERC process takes a minimum of 2 years to complete. It can take much longer if there are environmental issues that cannot be worked out with the agencies prior to submittal of the application to FERC.

Note that the process outlined in Appendix B assumes the NEPA compliance document is an environmental assessment, which is typical for small projects with few impacts. If the potential impacts are serious, then an environmental impact statement is required.

It may be possible to decrease FERC's involvement by developing the project first as a water supply project, and then adding the generating features later. Initially, the primary permitting authority would likely be the Corps of Engineers. Although that approach might delay 
generation by a year or two, it could be valuable because it could 1) minimize regulatory operating costs, and 2) make the generation "incremental hydro" and thus qualified for marketable tax credits.

\subsection{Cape Creeks Development}

\section{$\underline{\text { 3.3.1 Preliminary Layout }}$}

Four creeks drain off the north side of the Cape Flattery peninsula (from west to east they are Beach Creek, Middle Creek, Classet Creek, and Scow Creek). The combined flow of the four creeks may be enough to provide a reliable water supply, with hydroelectric development as a secondary use. The flow of the four creeks could be collected by a pipeline that would transport the water to Neah Bay. The most feasible route for the pipeline would be adjacent to the existing road around the Cape. If the Tribal Council elects to pursue this development further, then it will be necessary to have a plan and profile survey of the road.

When the Waatch River flow series described above is transposed to the Cape creeks, it indicates there would not be sufficient flow to meet the estimated water supply requirements without storage. The geology and topography of Beach Creek and Middle Creek are more favorable for reservoir development than Classet Creek and Scow Creek. The development concept evaluated by this study includes a 60-foot high dam on the west fork of Beach Creek.

The primary structures and facilities of the Cape Creeks development are summarized below and shown in Figure 11:

- A dam on the west fork of Beach Creek 60 feet high located 2,000 feet upstream of the road crossing.

- Small diversion structures on the east fork of Beach Creek, the west and east forks of Middle Creek, and on Classet and Scow Creeks.

- A surge tank about 70 feet high on the bluff above the western end of the Neah Bay breakwater

- A power plant at the abandoned truck scale near the west end of the Neah Bay breakwater. The power plant would contain two generating units. One generating unit would be dedicated to the water supply discharge, and would be sized at $12 \mathrm{~kW}$. The second generating unit would have an impulse-type turbine and direct-connected generator sized at about $500 \mathrm{~kW}$. The power plant would also contain the switchgear and control equipment necessary for unattended operation of the generating units.

- Approximately 1.6 miles of access roads to the storage dam on the west fork of Beach Creek and diversion structures, and approximately 1.3 miles of pioneer road along the main pipeline where it deviates from the existing road. Note that aerial photographs indicate the pioneer road would be mostly in old growth forest.

- Approximately 2.0 miles of $12.5 \mathrm{kV}$ transmission line to connect the power plant to the existing Neah Bay substation. 


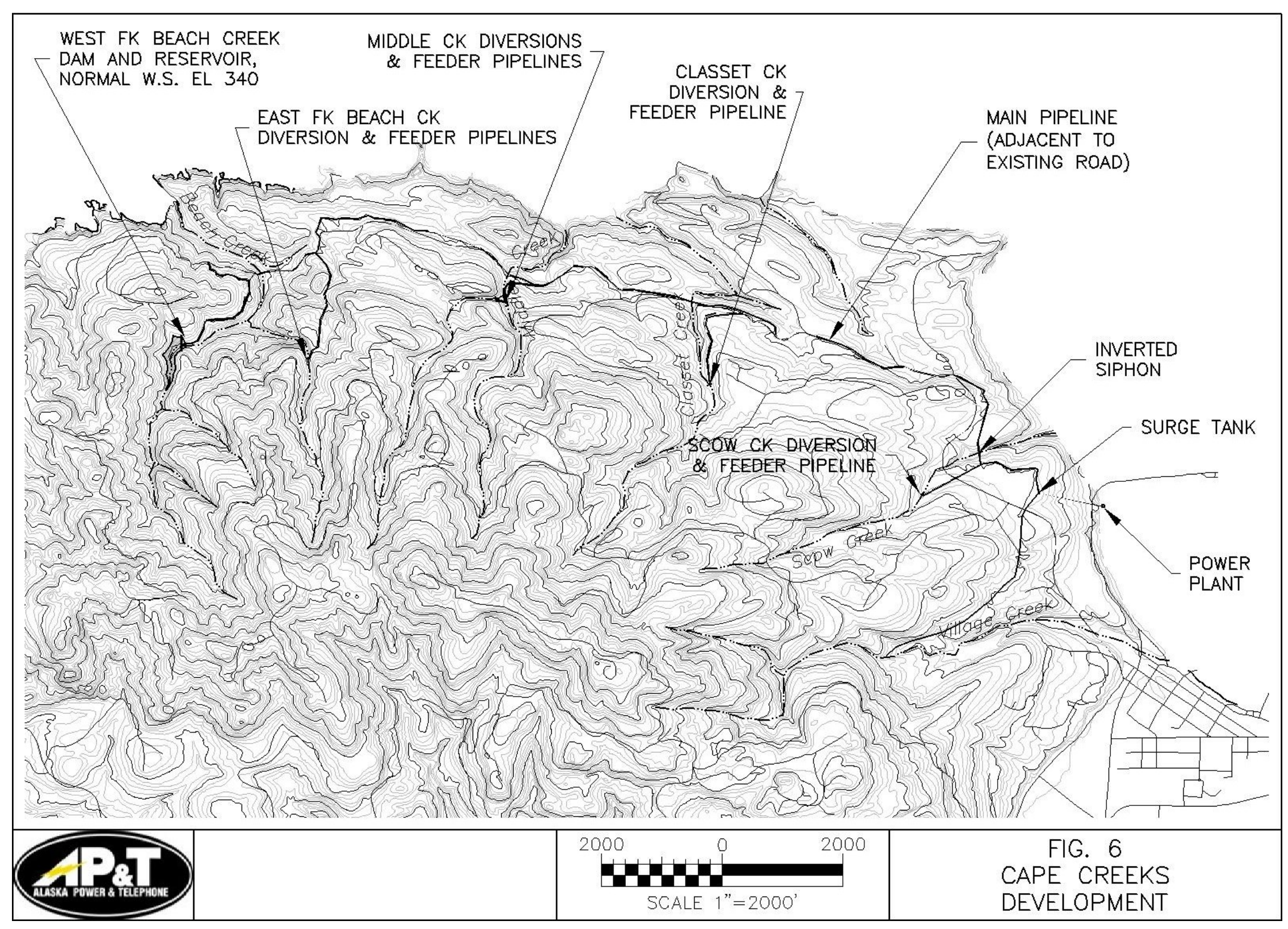

Figure 11, Cape Creeks Development 


\subsubsection{Water Supply and Generation}

Preliminary operations studies using the daily hydrologic record described above indicate that the proposed dam and reservoir would be adequate for the water supply during 25 of the 26 years of record. A taller dam would be necessary to provide a $100 \%$ reliable water supply, but the cost would be increased substantially. Detailed studies will be necessary to select the optimum size.

The power plant is estimated to generate an average of 1,300,000 kWh per year. Of that amount, only $50,000 \mathrm{kWh}$ is generated by the water supply unit. More detailed studies could determine that the water supply unit is not economical to install and operate.

\subsubsection{Cost Estimate}

The detailed construction cost estimate for the Cape Creeks hydroelectric development is provided in Appendix B. Table 8 shows the addition of the water treatment plant and operating costs over 50 years. The total construction cost is estimated to be $\$ 10,093,000$, excluding permitting and engineering, which could add an additional $\$ 1,000,000$ to the project cost.

Table 8, Cape Creeks Project Cost Estimates, Including O\&M

\begin{tabular}{|lrr|}
\hline \multicolumn{1}{|c}{ Item } & Amount \\
\hline Total Construction Cost, Dam and Powerplant & $\$ 7,815,000$ \\
Water Treatment Plant in Neah Bay & $5 \%$ & $\$ 1,752,000$ \\
$\quad$ Mobilization & $25 \%$ & 88,000 \\
Contingencies & $\$ 438,000$ \\
Total Construction Cost, Water Treatment Plant in Neah Bay & $\$ 2,278,000$ \\
& & \\
Total Construction Cost & $\$ 10,093,000$ \\
\hline & & \\
\hline Operating Costs (50 years) & $\$$ & 564,000 \\
Dam and reservoir & $\$ 1,047,000$ \\
Powerplant & $\$ 7,304,000$ \\
Water treatment plant & $\$ 8,915,000$ \\
\hline
\end{tabular}

\subsubsection{Potential Issues}

The following are brief descriptions of some potential issues associated with the Cape Creeks development:

- Because the developed creeks are not known to support salmon runs, no minimum flows have been assumed. Requirements to continuously release water to the streams below the diversions would adversely affect the generation by the power plant.

- The reservoir would be relatively small, and with low summer inflows, the water quality could be degraded by algae growth, similar to the current reservoir on Educket Creek. 
- The Middle Creek is used for ceremonial bathing prior to fishing trips and/or whale hunts. That use could easily be accommodated by releases from the diversion structures.

\subsubsection{Alternative Configurations}

A reasonable alternative site for a storage reservoir is on the West Fork of Middle Creek just upstream of its confluence with the East Fork. The project could be developed initially with one or the other of the reservoirs, and then the second reservoir added at a later date if it is found that additional storage is required.

Village Creek has not been included in the suggested development because it is known to support small runs of anadromous fish. A diversion on Village Creek and pipeline to the surge tank would be relatively economical to add now or at a later date if desired. Village Creek has a drainage area approximately equal to the other four streams, so the increase in total flow would be about $25 \%$. 


\subsection{Waatch River Development}

\subsubsection{Preliminary Layout}

The Waatch River has the greatest hydroelectric generating potential of all of the streams on the reservation. However, it is also one of the best salmon streams on the reservation and may be deemed off limits for hydroelectric development.

The features of the Waatch River development are:

- A dam on the east branch of the Waatch River, approximately 3.5 miles upstream from the confluence with Educket Creek, as shown in Figure 12. The dam would be constructed of roller compacted concrete, and an ungated overflow spillway would be located in the center of the dam. The dam would rise 110 feet above the streambed at El 390, and the active storage in the reservoir would be 1180 acre-feet (385 million gallons) between El 455 and $\mathrm{El} \mathrm{490.} \mathrm{An} \mathrm{intake} \mathrm{structure} \mathrm{would} \mathrm{draw} \mathrm{water} \mathrm{from} \mathrm{El}$ 450.

- A $35 \mathrm{~kW}$ power plant at the base of the dam for generating with the instream flow releases. A bypass system would be provided so that instream flows would continue in the event of an outage of the generating unit.

- The $900 \mathrm{~kW}$ power plant located shortly upstream of the existing water supply intake. The power plant would have the switching and control equipment for unattended operation. It would operate primarily during the fall, winter, and spring when there was more flow into the reservoir than needed for the instream flow releases.

- A power conduit from the dam to the main power plant. The power conduit would consist of 15,000 feet of 36” diameter HDPE pipe and 1,000 feet of 30” steel pipe.

- Approximately 3.6 miles of permanent new access road from the main power plant to the dam.

- Approximately 1.5 miles of $12.5 \mathrm{kV}$ transmission line to connect the power plant to the existing Neah Bay substation.

\subsubsection{Fisheries Issues}

Fishery impact mitigation potential could be provided by low-flow augmentation, since summer low flows currently limit the productivity of the Waatch River. Fish passage facilities could be provided at the dam, but they have not been considered herein because their effectiveness cannot be assured. The Waatch River development should only be considered if the Makah fisheries personnel believe the low flow augmentation would mitigate for the loss of the upstream habitat.

\subsubsection{Water Supply and Generation}

The water supply function would be provided by the instream flow releases, which are always greater than the maximum daily demand projected by the USBR in their April 2002 study. The water would be withdrawn from the river by the existing intake system.

The small power plant at the base of the dam would generate $160,000 \mathrm{kWh}$ in an average year, and the main power plant near the water supply intake would generate $3,100,000 \mathrm{kWh}$ in an average year. 


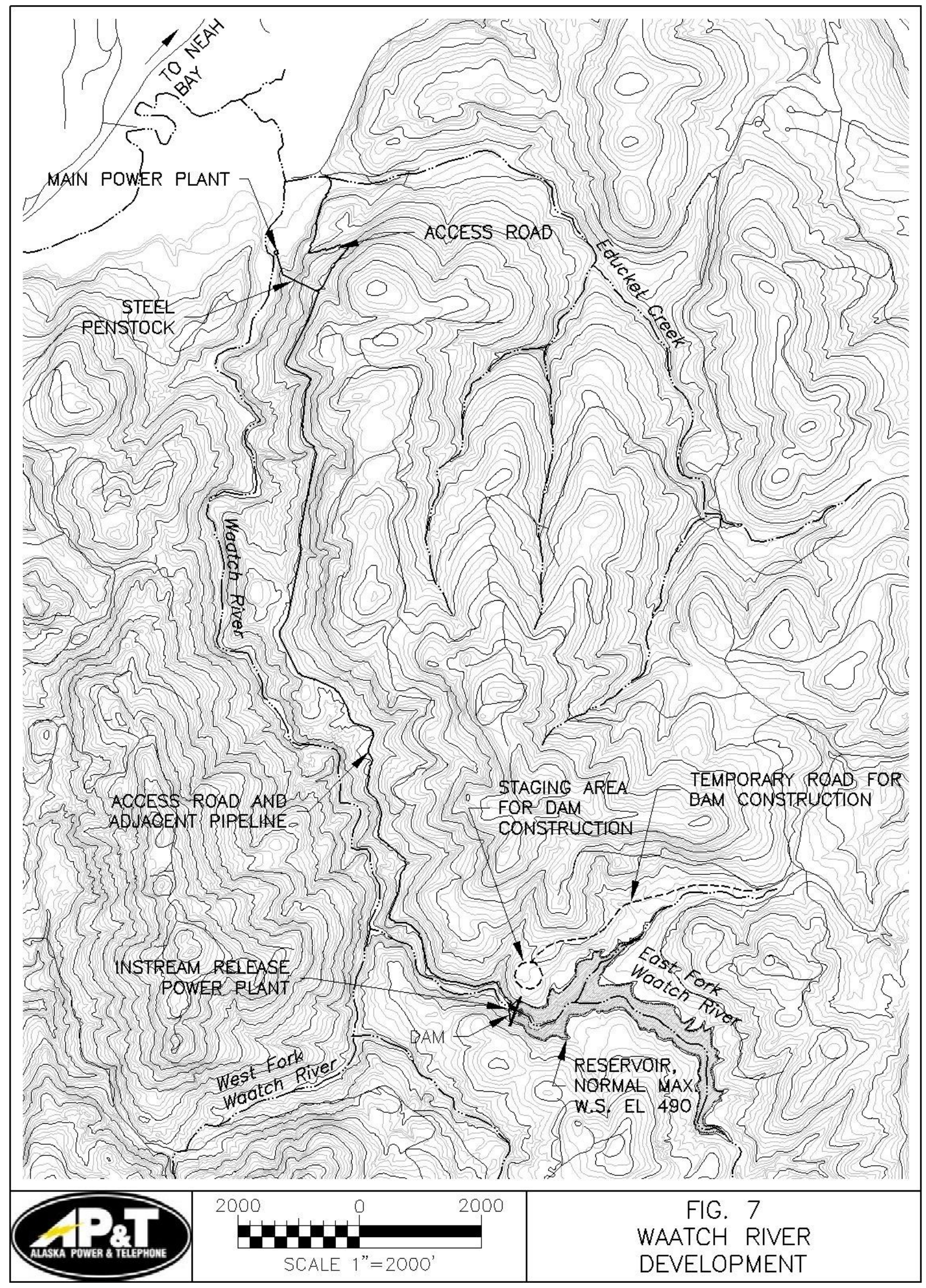

Figure 12, Waatch River Development 


\subsubsection{Cost Estimate}

The construction cost estimate for the Waatch River hydroelectric development is provided in Table 9. The total construction cost is estimated to be $\$ 14,974,000$. Permitting and engineering costs are not included and could be as much as $\$ 1,500,000$.

The largest cost is for the storage dam. The cost of the dam could vary significantly if the geology is unfavorable. Geologic mapping indicates the bedrock at the dam site is a sandstone, but it is known to be of lesser quality than rock on the Cape Flattery peninsula Detailed geotechnical investigations would be necessary to determine the actual rock characteristics. If the Council elects to pursue this development, a site visit and evaluation by a geologist or geotechnical engineer would be warranted.

Operating costs for the hydroelectric development are estimated to be about $\$ 90,000$ annually. That amount is based on labor for one half-time person being charged to the hydroelectric development. Note that modern hydro projects operate automatically, and only minor routine maintenance is usually required.

\subsubsection{Potential Issue}

The character of the bedrock at the damsite is unknown. The cost of the dam could vary significantly if the bedrock characteristics are unfavorable; the current cost estimated is based on excavation of approximately 10 feet of overburden and weathered rock. Detailed investigations would be necessary to determine the rock characteristics and their potential impacts on costs. Geologic mapping indicates that rock in the East Fork Waatch area is a sandstone, and likely to be less competent than the conglomerate found on the Cape Flattery peninsula.

\subsubsection{Alternative Configurations}

The project could be developed with only one power plant at the base of the dam. Its capacity would be only about $250 \mathrm{~kW}$, and the generation would be only about 750,000 kWh, but the cost and impacts of the road and long pipeline up the valley, as well as the second power plant, could be avoided.

The storage dam could also be placed below the confluence with the West Fork, which would nearly double the reservoir inflow. Generation and/or flow augmentation on the main branch could be increased significantly without much increase in cost. 
Table 9, Cost Estimate for Waatch Project

\begin{tabular}{|c|c|c|c|c|c|c|}
\hline Item & Quantity & Unit & & Unit Cost & & Amount \\
\hline Access Roads & 23,300 & LF & $\$$ & 25.00 & $\$$ & 583,000 \\
\hline \multicolumn{7}{|l|}{ Storage Dam and Reservoir } \\
\hline Reservoir clearing & 53 & Ac & $\$$ & 2,000 & $\$$ & 106,000 \\
\hline \multicolumn{7}{|l|}{ Diversion during construction } \\
\hline Cofferdam & 1,330 & $\mathrm{CY}$ & $\$$ & 25.00 & $\$$ & 33,000 \\
\hline Diversion conduit & 300 & LF & $\$$ & 200.00 & $\$$ & 60,000 \\
\hline Excavation & 17,000 & CY & $\$$ & 20.00 & $\$$ & 340,000 \\
\hline Foundation grouting & 2,250 & LF & $\$$ & 20.00 & $\$$ & 45,000 \\
\hline \multicolumn{7}{|l|}{ Concrete } \\
\hline Conventional concrete & 124 & $\mathrm{CY}$ & $\$$ & 600.00 & $\$$ & 74,000 \\
\hline Precast concrete & 41,000 & SF & $\$$ & 10.00 & $\$$ & 410,000 \\
\hline Roller compacted concrete & 66,600 & $\mathrm{CY}$ & $\$$ & 100.00 & $\$$ & $6,660,000$ \\
\hline \multicolumn{7}{|l|}{ Outlet works } \\
\hline Concrete & 44 & CY & $\$$ & 1,000 & $\$$ & 44,000 \\
\hline Trashrack & 1 & LS & $\$$ & 3,000 & $\$$ & 3,000 \\
\hline Bulkhead & 1 & LS & $\$$ & 5,000 & $\$$ & 5,000 \\
\hline Intake valve and operator & 1 & LS & $\$$ & 5,000 & $\$$ & 5,000 \\
\hline Release valve and operator & 1 & LS & $\$$ & 10,000 & $\$$ & 10,000 \\
\hline \multicolumn{7}{|l|}{ Instream Flow Powerplant } \\
\hline Foundation concrete & 25 & $\mathrm{CY}$ & $\$$ & 400 & $\$$ & 10,000 \\
\hline Metal building superstructure & 450 & SF & $\$$ & 75 & $\$$ & 34,000 \\
\hline \multicolumn{7}{|l|}{ Power conduit } \\
\hline Bifurcation & 1 & LS & $\$$ & 5,000 & $\$$ & 5,000 \\
\hline Pipe & 80 & LF & $\$$ & 200.00 & $\$$ & 16,000 \\
\hline Synchronous bypass valve & 1 & LS & $\$$ & 15,000 & $\$$ & 15,000 \\
\hline Turbine and generator & 1 & LS & $\$$ & 75,000 & $\$$ & 75,000 \\
\hline Control system & 1 & LS & $\$$ & 25,000 & $\$$ & 25,000 \\
\hline Transmission and communication lines & 15,000 & LF & $\$$ & 10.00 & $\$$ & 150,000 \\
\hline \multicolumn{7}{|l|}{ Main Powerplant } \\
\hline Foundation concrete & 48 & $\mathrm{CY}$ & $\$$ & 400.00 & $\$$ & 19,000 \\
\hline Metal building superstructure & 864 & SF & $\$$ & 75.00 & $\$$ & 65,000 \\
\hline \multicolumn{7}{|l|}{ Power conduit } \\
\hline Trashrack & 1 & LS & $\$$ & 15,000 & $\$$ & 15,000 \\
\hline Common Excavation (25\% of total) & 3,400 & $\mathrm{CY}$ & $\$$ & 3.00 & $\$$ & 10,000 \\
\hline Rock Excavation (75\% of total) & 10,100 & $\mathrm{CY}$ & $\$$ & 9.00 & $\$$ & 91,000 \\
\hline Bedding ( $10 \%$ of total) & 900 & $\mathrm{CY}$ & $\$$ & 25.00 & $\$$ & 23,000 \\
\hline Backfill ( $90 \%$ of total) & 8,400 & $\mathrm{CY}$ & $\$$ & 6.00 & $\$$ & 50,000 \\
\hline Intake valve & 1 & LS & $\$$ & 50,000 & $\$$ & 50,000 \\
\hline HDPE pipe & 15,000 & LF & $\$$ & 105.00 & $\$$ & $1,575,000$ \\
\hline Steel pipe & 1,080 & LF & $\$$ & 150.00 & $\$$ & 162,000 \\
\hline Turbine and generator & 1 & LS & $\$$ & 425,000 & $\$$ & 425,000 \\
\hline Control system & 1 & LS & $\$$ & 200,000 & $\$$ & 200,000 \\
\hline Transformer \& switch (pole mounted) & 1 & LS & $\$$ & 50,000 & $\$$ & 50,000 \\
\hline Transmission and communication lines & 1.5 & Mi & $\$$ & $50,000.00$ & $\$$ & 75,000 \\
\hline Subtotal & & & & & $\$$ & $11,518,000$ \\
\hline Mobilization & $5 \%$ & & $\$$ & 576,000 & & \\
\hline Contingencies & $25 \%$ & & $\$$ & $2,880,000$ & & \\
\hline Total Construction Cost, Dam and Powerplants & & & & & $\$$ & $14,974,000$ \\
\hline
\end{tabular}




\subsection{Cost of Energy for the Hydroelectric Projects}

Applying the same methodology used for the wind power stations in section 2.7.1 to the Cape Creeks and Waatch sites yields the results contained in Tables 10 and 11. A cost of capital fixed charge rate of $7 \%$ was used in the calculations and the annual O\&M costs were assumed to be partial time for one person plus minor electronic/electrical repairs.

Even with these low-cost assumptions, the cost-of-energy are very high:

- $\quad$ Cape Creeks - \$0.65 per kWh

- Waatch - \$0.38 per kWh

Neither of these projects can be justified as stand-alone power generation facilities, and must be viewed as potential water supply facilities.

Table 10, Simplified Cost of Energy for Cape Creeks Project

\begin{tabular}{|c|c|}
\hline Item & $\begin{array}{c}\text { Estimated } \\
\text { Values }\end{array}$ \\
\hline Project capacity (MW) & 0.512 \\
\hline Project life (years) & 50 \\
\hline Fixed charge rate & $7.0 \%$ \\
\hline Total capital cost & $\$ 11,093,000$ \\
\hline Annualized amortization (FCR x Capital Cost) & $(\$ 803,797)$ \\
\hline Annual operation \& maintenance cost $t^{1}$ & $(40,000)$ \\
\hline Total annualized cost & $(843,797)$ \\
\hline Annual net kWh & $1,300,000$ \\
\hline Cost of energy (COE) before royalty payments & $(0.65)$ \\
\hline
\end{tabular}

Table 11, Simplified Cost of Energy for Waatch Project

\begin{tabular}{|l|c|}
\hline Item & $\begin{array}{c}\text { Estimated } \\
\text { Values }\end{array}$ \\
\hline Project capacity (MW) & 0.935 \\
\hline Project life (years) & 50 \\
\hline Fixed charge rate & $7.0 \%$ \\
\hline Total capital cost & $\$ 16,440,000$ \\
\hline Annualized amortization (FCR x Capital Cost) & $(\$ 1,191,240)$ \\
\hline Annual operation \& maintenance cost ${ }^{1}$ & $\$ \quad(40,000)$ \\
\hline Total annualized cost & $\$(1,231,240)$ \\
\hline Annual net kWh & \multicolumn{2}{|c|}{$3,260,000$} \\
\hline Cost of energy (COE) before royalty payments & $\mathbf{\$}$ \\
\hline
\end{tabular}




\subsection{Conclusions, Lessons learned, and Recommendations for Hydroelectric Projects}

\section{Conclusions and Lessons Learned}

1. The potential for hydroelectric development on the Makah Reservation is quite limited due to the small size of most of the streams and the existence of significant salmon runs in the larger streams. There does not appear to be any project that can be developed economically solely on the basis of energy sales without very substantial subsidization.

2. Because there is a critical need for a dependable, good-quality water supply for Neah Bay, the best chance for hydroelectric development may be in conjunction with a water supply development.

3. The quality of the Cape Creeks water supply could deteriorate during the summer because of the limited storage volume. The Waatch River development would provide a better quality water supply because of the much larger reservoir, but there are fisheries impacts that may or may not be completely mitigated by the low-flow augmentation function of the reservoir.

\section{Recommendations}

1. The Tribal Council should not pursue development of hydroelectric facilities on the Makah Reservation unless they are an adjunct to a water supply development. Standalone hydroelectric development is not economical without substantial subsidization.

2. If the Tribal Council wishes to pursue one of the Cape Creeks or Waatch River developments described herein, then the Tribal Council should first conduct a feasibility-level evaluation, including more detailed analyses of the probable water quality, environmental impacts, engineering, and economics. 
